\title{
Dynamics of Electricity Production against the Backdrop of Climate Change: A Case Study of Hydropower Plants in Poland
}

\author{
Katarzyna Kubiak-Wójcicka ${ }^{1, * \mathbb{D}}$ and Leszek Szczęch ${ }^{2}$ (D) \\ 1 Faculty of Earth Sciences and Spatial Management, Nicolaus Copernicus University, Lwowska 1, \\ 87-100 Toruń, Poland \\ 2 Faculty of Mechanical Engineering, Military University of Technology, Gen. Sylwestra Kaliskiego 2, \\ 00-908 Warszawa, Poland; leszek.szczech@wat.edu.pl \\ * Correspondence: kubiak@umk.pl
}

check for updates

Citation: Kubiak-Wójcicka, K.; Szczęch, L. Dynamics of Electricity Production against the Backdrop of Climate Change: A Case Study of Hydropower Plants in Poland. Energies 2021, 14, 3427. https:// doi.org/10.3390/en14123427

Academic Editor: Chirag Trivedi

Received: 25 April 2021

Accepted: 5 June 2021

Published: 10 June 2021

Publisher's Note: MDPI stays neutral with regard to jurisdictional claims in published maps and institutional affiliations.

Copyright: (c) 2021 by the authors. Licensee MDPI, Basel, Switzerland. This article is an open access article distributed under the terms and conditions of the Creative Commons Attribution (CC BY) license (https:// creativecommons.org/licenses/by/ $4.0 /)$.

\begin{abstract}
Renewable energy sources (RES) play an important role in the European Union's energy sector as a result of the energy policy framework adopted. Its share in the final energy consumption varies depending on the country and the adopted energy policy. The article presents the structure of electricity production from renewable energy sources in Poland in the years 2002-2019. It was found that the share of energy production from hydroelectric power plants in Poland in relation to the amount of energy produced from renewable energy sources in the analyzed years has strongly decreased. The reason for this state was an increase in the production of energy coming from wind and biomass energy combined with an increase in subsidies for these energy producers. Additionally, unstable hydrological conditions, mainly low river flows, may be the reason for the low share of energy produced in power plants. As a case study, data for five small hydropower plants (SHP) located on the Gwda river (north-western Poland) were analyzed. Electricity production volumes were analyzed depending on the size of the Gwda river flow. It was found that the lower amount of electricity produced at SHPs on the Gwda river is mainly due to lower flows in the river. In the future, unstable electricity production from renewable energy sources may have a significant impact on achieving Poland's energy targets in 2030.
\end{abstract}

Keywords: renewable energy sources (RES); hydroelectricity; small hydropower plant (SHP); Poland

\section{Introduction}

Climate changes that we have observed over the last few decades have a significant impact on the economy. This is especially true in the energy sector, which uses renewable energy sources to produce electricity. Forecasts for the future indicate that the demand for electricity will grow. In this context, the uncertain amount of electricity produced may lead to an imbalance in energy security. According to the European Energy Agency, global climate change is one of the greatest environmental, social, and economic threats [1,2]. Research on climate change forecasts indicates that extreme weather conditions, including heatwaves, droughts, and floods, will become more frequent and intense. The impact of these phenomena will have different effects in different regions of the world. In particular, dry and semi-arid areas of Africa [3,4], Asia [5], and Australia [6] will be exposed to more severe and long-lasting droughts. In Europe, the greatest increase in air temperature is forecasted to occur in the south of the continent and in the Arctic region [7]. The amount of precipitation will decrease in southern Europe and increase in the north and northwest $[2,8]$. In the light of these forecasts, the impact of climate change on energy produced from renewable sources was estimated. Much of the attention was devoted to climate change and its impact on the state of water resources and electricity production in hydropower plants in a global or regional perspective [9-16] or nationally [17-21].

Some of these studies indicate that climate change could reduce the useful hydropower capacity in 60-75\% of the world's hydropower plants by 2040-2069. Authors found that 
regions with a "significant $(>20 \%)$ decline" in hydropower capacity include Southern Europe, North Africa, the Southern United States, parts of South America, South Africa, and South Australia [22,23]. The greatest drops in electricity production are forecast in regions that are considered water-rich. Estimates carried out for selected rivers of South America indicate that a reduction in annual precipitation totals, and hence flows in rivers, which are forecast from 25 to $50 \%$, may lead to a decrease in electricity production by about $60 \%$ [24]. According to authors [25], due to climate change, hydropower production in Colombia by 2050 could decline by $10-15 \%$. In the Zambezi basin, a reduction in water resources will lead to a reduction in hydropower production potential by $9 \%$ in 2020 , $18 \%$ in 2050, and $28 \%$ in 2080 [4]. In India, on the other hand, an increase in the amount of electricity produced in hydropower plants is forecast by approx. $25 \%$ as a result of an increase in flow in rivers caused by power supply from the Himalayan region (snow melting) [26].

The information obtained is disturbing and in the perspective of further climate changes may constitute an important element of the energy security strategy of individual countries or communities. Climate changes, visible both in observations and forecasts, are manifested in an increase in air temperature and a change in the structure of atmospheric precipitation. Both of these factors have a direct, complex impact on hydrology and water resources [27]. The energy system becomes more and more exposed to limited water availability and its increased temperature, causing temporary shutdowns of energy facilities, which poses a threat to energy infrastructure $[28,29]$. Understanding the energy system's water needs and its future evolution provide valuable information on its potential impact on water resources. Assessment of the availability of future water resources helps to identify areas at risk and informs about the need to develop a policy for solving problems related to hydropower [30].

The problem of hydropower varies depending on the region, available water resources, and the adopted energy policy of a given country. Poland is not one of the regions that are among the big losers as a result of climate change, but the threats associated with extreme hydrological phenomena-floods and droughts - may intensify [31]. In addition, Poland is one of the countries with the lowest water resources and has a small technical hydropower potential among the European Union countries [32,33].

This study shows the threat to electricity production as a result of climate change. In order to assess the current state of knowledge on the subject and identify research priorities, the article reviews critically the literature on the impact of climate change on the energy supply system, summarizing the global scope of research, trends in their results, and sources of inconsistencies. The purpose of this article is to assess the impact of the decline in water resources on the amount of electricity generated in the Gwda river basin in north-western Poland. The Gwda river was selected as the case study due to its over one hundred years of energy use and quite significant water resources, slightly exceeding the average values for Poland.

\section{Materials and Methods}

Scientific literature as well as reports and accounts available on the websites of various state institutions were used to characterize the issues of hydropower development in Poland. The characteristics of the share of electricity produced in Poland compared to other renewable energy sources were discussed on the basis of the statistical data of the Central Statistical Office [34] from 2002-2019. Information on the total number of renewable energy installations in Poland, confirmed by certificates of origin, was obtained from the Energy Regulatory Office [35].

A detailed analysis of the impact of climate change on the volume of electricity production was carried out on the example of the Gwda river in north-west Poland. To discuss climate changes, the meteorological data for two meteorological stations, i.e., Chojnice and Piła, were used, which represent meteorological conditions in the upper and lower parts of the Gwda catchment, respectively. The meteorological data includes 
daily values of precipitation and air temperature. The hydrological conditions were characterized on the basis of the flow data of the Gwda river at the Piła hydrometric station. Meteorological and hydrological data cover the period of 1990-2019 and were obtained from the Institute of Meteorology and Water Management-National Research Institute (IMWM-NRI).

Data on the volume of produced energy and the flow through the turbines, broken down by month in the years 1982-2011, were obtained for 5 hydropower plants (Podgaje, Jastrowie, Ptusza, Dobrzyca, and Koszyce) located on the Gwda River. The data was made available by Energy Service Company Jastrowie, which administered these facilities.

The gross capacity of the river hydroelectric power plant can be calculated as:

$$
P=\rho \times g \times Q \times H[\mathrm{~W}]
$$

where $P$ is the hydropower $(\mathrm{W}), \rho$ is the water density $\left(\mathrm{kg} / \mathrm{m}^{3}\right), g$ is the acceleration due to gravity $\left(9.81 \mathrm{~m} / \mathrm{s}^{2}\right), Q$ is the outflow $\left(\mathrm{m}^{3} / \mathrm{s}\right)$, and $H$ is the height of the fall $(\mathrm{m})$.

The maximum annual energy production is reached when $100 \%$ of the annual runoff is used to generate hydropower production (i.e., gross potential).

Basically, the power that can be obtained in a hydropower plant depends on the water flow rate $Q$, the height of the fall $H$, and efficiency of hydropower unit $\eta_{e}$. On the base of monthly flows and water height of the fall and electricity production in chosen hydropower plants, it was possible to calculate the level of their efficiency.

$$
\eta_{e}=\frac{E}{730 \times 9.81 \times Q \times H} \times 100 \%
$$

where $E$-monthly electricity production, $[\mathrm{kWh}], 730$-average number of hours during month.

Correlation analysis was carried out in order to determine the impact of water flow on the volume of electricity production in hydropower plants located in the Gwda Cascade.

Coefficient of correlation $r$ was calculated on a base of equation:

$$
r=\frac{\sum_{i=1}^{n}\left(x_{i}-\bar{x}\right) \times\left(y_{i}-\bar{y}\right)}{\sqrt{\sum_{i=1}^{n}\left(x_{i}-\bar{x}\right)^{2} \times \sum_{i=1}^{n}\left(y_{i}-\bar{y}\right)^{2}}}
$$

where $x$ is quantity of water flow in every month of a year, $y$ is a quantity of electricity production, at the same time, in the analyzed hydropower plant.

Quantities of a correlation coefficient $r$ should be placed in the range of $(-1 ; 1)$; correlation coefficient equal to 1 means strong proportional correlation, -1 means strongly inversely proportional. Quantity equal to 0 means that there is no correlation between compared waveforms.

\section{Energy Policy of the European Union and Poland in the Field of Renewable Energy Sources}

To effectively reduce the scale of global warming, the global economy must start using energy in an economical way as soon as possible, while replacing conventional energy sources with renewable energy sources. Counteracting the effects of climate change is an important element of the European Union's strategy. Actions taken by the European Commission are directed towards an energy strategy for a safer, sustainable, and lowcarbon economy [36]. The European Union countries currently number 27 countries, which constitute about $40 \%$ of the area of Europe and about $60 \%$ of the population inhabiting the European continent. The energy policy of the European Union in recent years has been largely focused on supporting the development of renewable energy.

The climate and the energy package are important elements of the European Union's energy policy, based on the belief that energy supplied to consumers should be sustainable, competitive, and affordable. This policy is the basis for the transformation of the European 
energy system, with particular emphasis on renewable energy. The provisions on the use of renewable energy sources have been included in strategic documents that include the regulatory framework $[37,38]$.

The EU's long-term climate objectives are part of a broader policy framework such as the "Energy Union Strategy", which serves and benefits from long-term policy coherence. Without a clear political vision and strong political commitment over time, investors, producers, and consumers will not be inclined to adopt solutions that they may perceive as risky investments [39].

In 2009, EU leaders set a target that by 2020, 20\% of energy consumption in the Union should come from renewable sources [37]. In 2018, a target for 2030 was agreed: by then, $32 \%$ of energy consumption in the EU is to come from renewable sources $[40,41]$. To achieve its target, the EU has established new rules for future financial support for renewable energy sources and for promoting the right of citizens to produce their own renewable energy. In addition, in order to achieve the assumed share of electricity production from renewable sources, binding targets have been set for individual Member States. The common policy of the European Union countries has a decisive influence on the decisions taken by the governments of individual countries and the implemented energy strategies.

According to a report published in early 2021 [42], in 2020, for the first time, renewable sources had a greater share of energy production than fossil fuels. The difference was small, as in the EU as a whole, 38\% of electricity was produced from renewables, $37 \%$ from fossil fuels, and the remaining $25 \%$ from nuclear energy. The large share of energy produced from renewable sources in the entire EU is the result of investments in renewable energy sources in individual EU countries. The countries that already in 2019 exceeded the assumed share of energy produced from renewable energy sources include, among others, Sweden, Finland, and Denmark. Among the countries that did not achieve the target in 2020, were countries such as France, the Netherlands, and Poland. According to the data from 2020, Poland and the Czech Republic are the only two countries where the amount of energy generated from burning fossil fuels was more than four times greater than that generated from renewable sources [42].

Member States have different renewable energy potentials and operate different support schemes at the national level. According to the research conducted by [43], Poland together with Malta, Slovakia, Greece, Cyprus, and Bulgaria are the countries with the worst results in terms of the use of renewable energy (with index values below the first quartile).

Poland has adopted the most important documents in the field of the country's energy policy, including Poland's energy policy until 2030 in 2009 [44], the strategy "Energy security and the environment-a perspective until 2030" [45], and the currently binding Polish Energy Policy until 2040 [46]. In these documents, Poland specified the amount of electricity produced from renewable sources at 15\% in 2020 and $23 \%$ in 2030 . In domestic conditions, energy from renewable sources includes energy from solar radiation, water, wind, geothermal resources, energy generated from solid biofuels, biogas and liquid biofuels, as well as ambient energy obtained by heat pumps. Among the energy produced from renewable sources, the majority of energy comes from the use of wind, water, and solar radiation, i.e., depending on meteorological conditions. There is therefore a risk that the achievement of the 2030 target will also be jeopardized, especially in the event of changing climatic conditions.

According to the strategy document [46], in 2040, more than half of the installed capacity will comprise zero-emission sources. A special role in this process will be played by the implementation of offshore wind energy into the Polish power system and the commissioning of a nuclear power plant. These will be two strategic new areas of the industry that will be built in Poland. 


\section{Poland's Hydropower Potential and Production Compared to Other Renewable Energy Sources}

\subsection{Poland's Hydropower Resources and Potential Ubsection}

Poland is a country with scarce water resources [47]. Despite the favorable layout of the hydrographic network, the average unit runoff from the 1951-2015 period in the Vistula basin was $5.4 \mathrm{dm}^{3} / \mathrm{s} . \mathrm{km}^{2}$ (average flow $1044 \mathrm{~m}^{3} / \mathrm{s}$ ) and in the Oder basin $4.7 \mathrm{dm}^{3} / \mathrm{s} . \mathrm{km}^{2}$ (average flow $522 \mathrm{~m}^{3} / \mathrm{s}$ ) [48]. For example, the water resources of the Elbe river were around $6 \mathrm{dm}^{3} / \mathrm{s} \cdot \mathrm{km}^{2}$ (average flow $862 \mathrm{~m}^{3} / \mathrm{s}$ ) [49], while the Danube, the largest river in Europe, was around $8 \mathrm{dm}^{3} / \mathrm{s} . \mathrm{km}^{2}$ (average flow $6480 \mathrm{~m}^{3} / \mathrm{s}$ ) [50].

The average amount of water per capita in Poland in the years 1951-2015 was $1600 \mathrm{~m}^{3}$, which is the fourth place from the end in Europe. Only the Czech Republic, Malta, and Cyprus had lower resources than Poland [51]. Low water resources result from small sums of precipitation and a small capacity of water reservoirs, which retain water flowing out of Poland to a small extent. The total amount of water accumulated in 69 artificial reservoirs with a capacity of more than 5 million $\mathrm{m}^{3}$ is 3678 million $\mathrm{m}^{3}$, which is about $6 \%$ of the average annual total runoff from the multi-year period 1951-2015 [48].

Conceptual work on the development of the Vistula river has been carried out since the beginning of the 20th century [52]. They included the construction of a cascade of barrages with retention reservoirs and the installation of hydropower plants. The theoretical water resources of Polish rivers were identified in the 1960s on the basis of the methodology of the World Energy Council. The calculations made by A. Hoffmann [53] show that the theoretical energy resources of Polish rivers average $2625 \mathrm{MW}$ of power and about $23 \mathrm{TWh} /$ year. Technical resources of all flowing waters in Poland amount to $14 \mathrm{TWh} / \mathrm{year}$, which is $61 \%$ of all theoretical resources. Compared to other European countries, this potential is small [54]. Sweden, France, and Italy have the greatest technical potential of flowing water (100 TWh/year). The technical potential of Germany and Portugal is around 25 TWh/year. The Czech Republic, Lithuania, Latvia, and Slovakia have lower technical potential than Poland [55].

The geographic distribution of this potential is as follows:

- Vistula basin-9.3 TWh/year, including the Vistula river 6.2 TWh/year,

- Oder river basin-2.5 TWh/year, including the Oder river 1.8 TWh/year,

- coastal rivers basin-0.3 TWh/year,

- $\quad$ small hydropower plants-2.0 TWh/year.

Poland's energy potential is unevenly distributed. The largest energy resources are in the lower Vistula (from Warsaw to the estuary to the Baltic Sea). There were several concepts for the energetic use of this section of the Vistula in the form of a cascade of water steps. Depending on the concept, the number of steps ranged from 8 to 12 [56]. Ultimately, out of the planned cascade of eight steps, only one water barrage on the lower Vistula was implemented-with a hydroelectric power plant in Włocławek with a capacity of $160.2 \mathrm{MW}$. The calculations made by authors [57] shows that, depending on the adopted variant of the installed flow, the total power of the cascade may range from 507.1 MW to 857.4 MW, which enables an average annual energy production amounting to $3428.4 \mathrm{GWh}$ to $4221.1 \mathrm{GWh}$, respectively. The amount of electricity produced from the designed cascade of the lower Vistula river would constitute from $2.1 \%$ to $2.6 \%$ of the total electricity produced in Poland. The obtained results indicate that the possible implementation of a cascade of damming barrages together with hydropower plants on the lower Vistula river will make a significant contribution to energy production in the National Power System.

\subsection{History of the Development of Hydropower in Poland}

Initially, water energy was used to power grain mills, paper mills, fulling mills, and others. In the first place, mainly small watercourses were adopted for energy purposes. Information about the first water mills in Poland appeared around the 11th century, and became popular in the 13 th century $[58,59]$. The systematic development of water mills took place until the 18th century. It developed most intensively in the northern and central 
part of the country, mainly in lake districts and lowlands. From the mid-nineteenth century, the number of water mills began to decline significantly. They were replaced by more effective steam mills [60]. Only some of these facilities were gradually rebuilt until World War II. As a result of the inventory carried out in Poland in 1954, 6330 water-powered facilities (water mills, sawmills, paper mills) were active, and 800 were closed [61]. Rapid industrialization, progressive electrification of the countryside, low energy prices, and government policy were not conducive to the use of such small facilities. As a result of the policy pursued until 1960, most of the water mills were closed or fitted with electric drives.

The largest hydropower investments in Poland were carried out in the years 19601970. At that time, the largest run-of-river power plant was built on the Vistula river in Włocławek (160.2 MW), which was to be one of several elements of the so-called Cascades of the Lower Vistula. The turn of the 1970s and 1980s was the period of great Polish pumped storage power plants. Two hydropower giants were created then: Porabka-Żar (500 MW) in 1979 and Żarnowiec (680 MW) in 1982 [52,62]. Later, work on large hydrotechnical facilities was abandoned due to the economic crisis. The return to the hydropower development of the Lower Vistula took place only at the beginning of the second decade of the 21st century, when the location of the next barrage downstream of Włocławek was considered. Out of four possible variants of the location of the new barrage, Siarzewo was selected due to the possibility of permanent protection of the Włocławek barrage [63]. The location of the Siarzewo barrage was approved in 2012 and since then, preparatory and design work has been carried out. The construction of the Siarzewo barrage is planned to start in 2023 and be completed in 2029. The investment in Siarzewo is of great interest because of its ecological, economic, and social effects; all the more so because in some regions of the world, dams on rivers and the reservoirs they create are being removed [64].

Changes in the approach to the use of rivers for energy purposes took place only in the 1980s, when regulations were introduced that a private entity may become the owner of a low-power hydroelectric power plant (below $5 \mathrm{MW}$ ). Most of the hydrotechnical facilities were state-owned, while facilities with very low power, most often below $0.5 \mathrm{MW}$ or requiring significant renovation, were transferred to private hands. In total, about 650 facilities with a total capacity of about $80 \mathrm{MW}$ were reconstructed [61].

In Poland, small water power plants are considered to be facilities that generate electricity or mechanical energy by converting the power available in the waters of flowing rivers, canals, and streams with an installed capacity of up to $10 \mathrm{MW}$. The $10 \mathrm{MW}$ limit is generally accepted by the European Commission (EC), the European Small Hydropower Association (ESA), and the Society for the Development of Small Hydropower Plants in Poland. In other countries around the world, small hydropower plants are considered to be larger power plants, e.g., in China, it is $50 \mathrm{MW}$ [65].

According to the data of the Energy Regulatory Office [66], as of December 31, 2019, there were 771 licensed hydropower plants in operation in Poland, including:

(a) 13 hydropower plants with a capacity above $10 \mathrm{MW}$, including three hydropower plants only with pumped storage,

(b) 68 run-of-river power plants up to $10 \mathrm{MW}$,

(c) 106 run-of-river power plants up to $1 \mathrm{MW}$,

(d) 587 run-of-river power plants up to $0.3 \mathrm{MW}$.

Despite the attractiveness and advantages of small hydropower plants (SHP), unlike large plants (above $10 \mathrm{MW}$ ), a significant part of the SHP potential remains unused. It is estimated that in Poland, there are over 8000 locations that have been inventoried on the Restore Hydro project [67].

Increased interest in the construction of small hydropower plants in Poland was recorded at the beginning of the 21st century and was related to co-financing of facilities with a capacity of up to $10 \mathrm{MW}$. The source of support for new SHP facilities located on the site of former dams was co-financed by the EU Cohesion Fund in 2007-2013 under the Operational Program Infrastructure and Environment entitled: "Generation of energy from renewable sources". In 2014-2021, co-financing for the modernization of hydropower 
plants with a capacity of up to 2 MW came from the funds of the Financial Mechanism of the European Economic Area 2014-2021 under the program: "Renewable Energy, Energy Efficiency, Energy Security". Planned support under this program amounted to approx. EUR 3 million, which can be used for the modernization of only 3-4 small hydropower plants. The demand for co-financing projects related to the modernization of the existing small hydropower plants is much greater. Modernization of small hydropower plants is aimed at increasing the efficiency of energy production from renewable sources and reducing the potential negative impact on the environment. The currently functioning support systems for small hydropower in the form of various types of certificates are not sufficient to reduce investors' costs of building these types of facilities, especially their modernization in the long-term of their life cycle. It should be noted that the facilities that require modernization require significant financial outlays. Most of the small hydropower plants are facilities that have been in operation for over several dozen years and are monuments of hydraulic engineering.

\subsection{Electricity Production in Hydropower Plants Against the Backdrop of Renewable Energy Sources}

According to the data of the Central Statistical Office [34], the total amount of electricity produced in Poland in 2019 was 163,988.5 GWh. The analysis of statistical data provided by the Central Statistical Office [34] made it possible to determine the amount of electricity produced from various sources (Figure 1). The largest increase was recorded in power installations in wind farms (intensive increase since 2010) and power plants based on solid biofuels (since 2012). Since 2011, it has been recording an increase in installed capacity in solar energy. Due to numerous investments in renewable energy sources, in particular in wind and solar energy, the structure of installed capacity in individual types of power plants has changed. In the structure of using renewable energy sources for electricity production, the share of wind energy has been increasing, while the share of water energy and solid biofuels has decreased. In recent years, there has also been a rapid increase in electricity production from photovoltaic cells-in 2019, it was 136.5\% higher compared to 2018 and more than 12 times higher than in 2015. A report published by the solar industry association Solar Power Europe shows that in 2020, the power of connected PV installations in Poland amounted to 2.2 GW (twice as much as in 2019) [68].

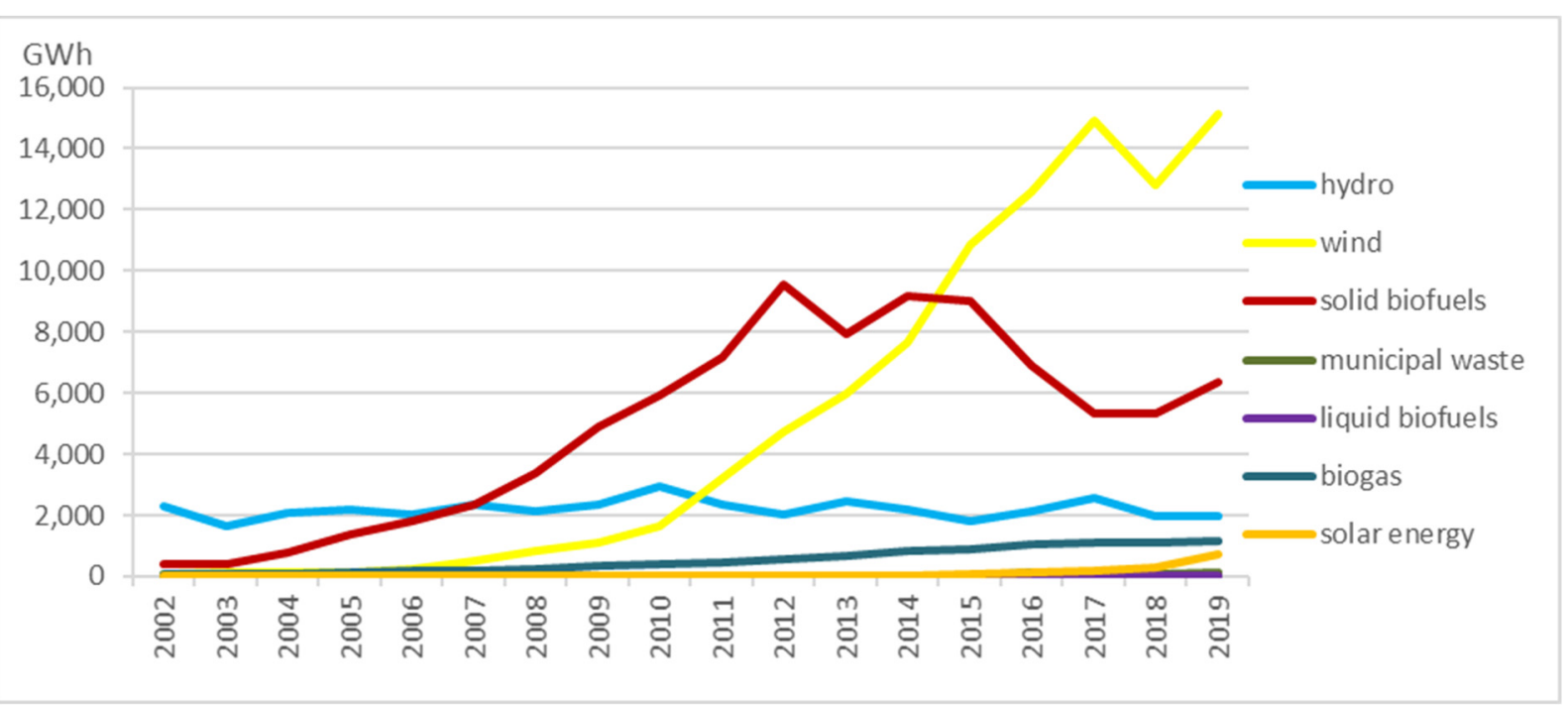

Figure 1. The structure of electricity production from renewable energy sources in Poland in 2002-2019 (based on data from the Central Statistical Office).

Solar and wind energy are slowly becoming significant players in the Polish energy sector. This is especially visible from the perspective of their installed capacity, which at the 
end of 2020 amounted to $3420 \mathrm{MW}$ and $6347 \mathrm{MW}$, respectively. Although these capacities account for $19.8 \%$ of the total installed capacity, the share of solar and wind energy in meeting the domestic electricity demand is relatively low, 1.4\% and 9.2\%, respectively [69].

For comparison, two years were compared, i.e., 2002 and 2019, for which the structure of electricity production from renewable sources was presented (Figure 2). In 2002, the amount of electricity produced in hydropower plants accounted for $82.4 \%$ in the RES structure, while in 2019, it was only 7.7\%. In 2019, the structure of electricity production was dominated by energy produced in wind farms, constituting $59.4 \%$ of the total energy produced from renewable sources.

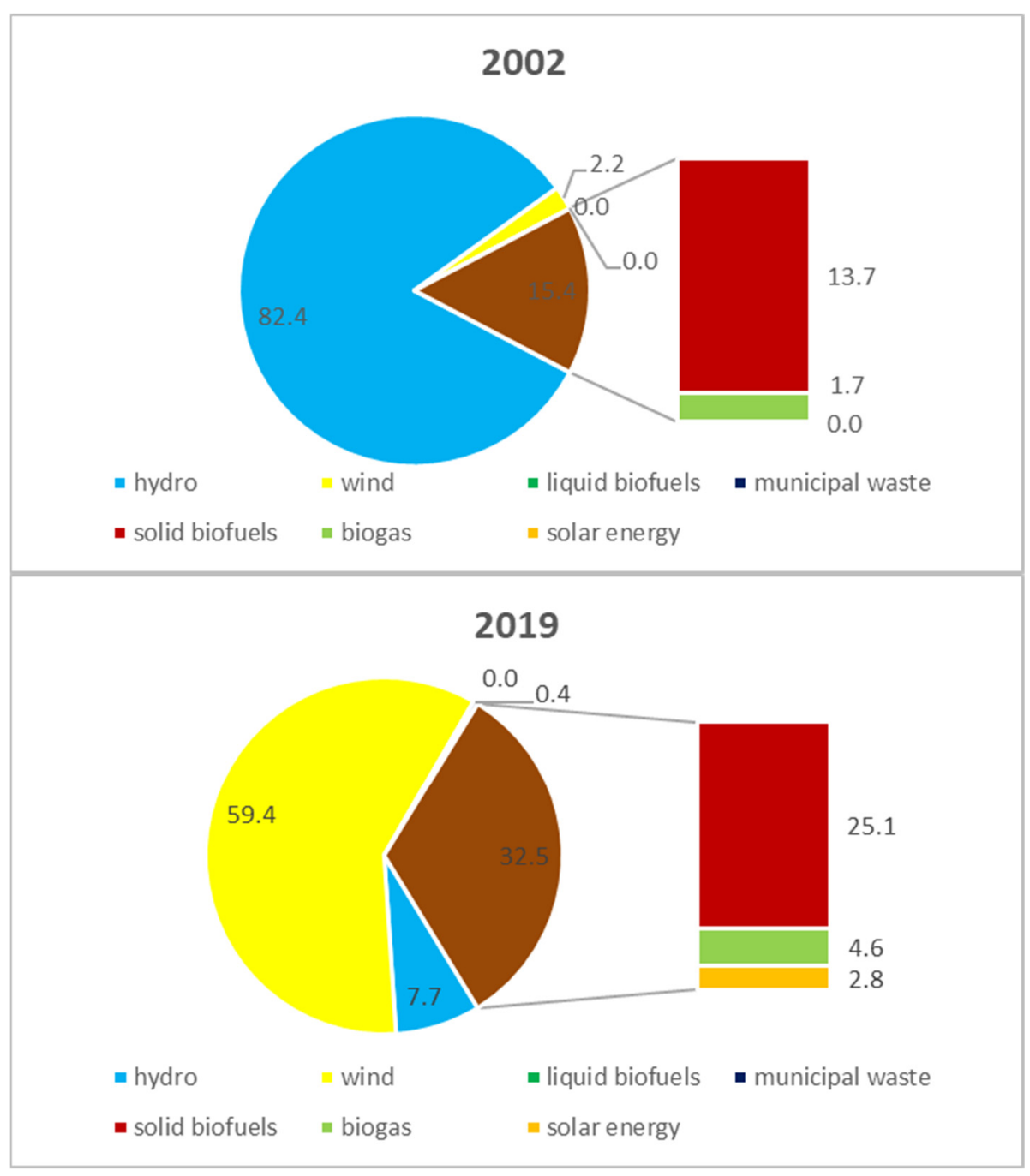

Figure 2. The structure of electricity production (in \%) from renewable sources in Poland in 2002 and 2019 (based on data from the Central Statistical Office).

The volume of electricity production in hydropower plants, broken down into three ranges of available power (<1 MW; 1-10 MW; >10 MW) in the years 2002-2019, is shown in Figure 3. Electric energy produced in small hydroelectric power plants $(<1 \mathrm{MW})$ and medium power (1-10 MW) tend to be fairly stable without sharp ups and downs. Exceptions were made in 2003, 2010, and 2015. The year 2010 was one of the most wet years in Poland, especially in the Vistula basin [70]. On the other hand, dry years were recorded in 2003 and 2015, and the production of electricity in hydropower plants was lower than the average value in the analyzed multi-year period. This problem mainly concerned hydropower plants with a capacity of more than $1 \mathrm{MW}$. In dry years, with very low flows, small hydropower plants with a capacity of less than $1 \mathrm{MW}$ did not work due 
to the insufficient amount of water and the obligation to maintain an intact flow in the river beds. For example, in 2015, during long-term drought in the summer months, no flow was recorded in small watercourses [71]. In high-capacity hydroelectric power plants (>10 MW), significantly greater increases and decreases can be observed compared to the previous year, which fluctuate by $+/-30 \%$. The main reason for this is the meteorological conditions that affect the amount of flows in rivers, which translated into the amount of electricity produced. The amount of produced energy is also influenced by renovation works carried out on barrages in large hydropower plants, as a result of which electricity production is interrupted.

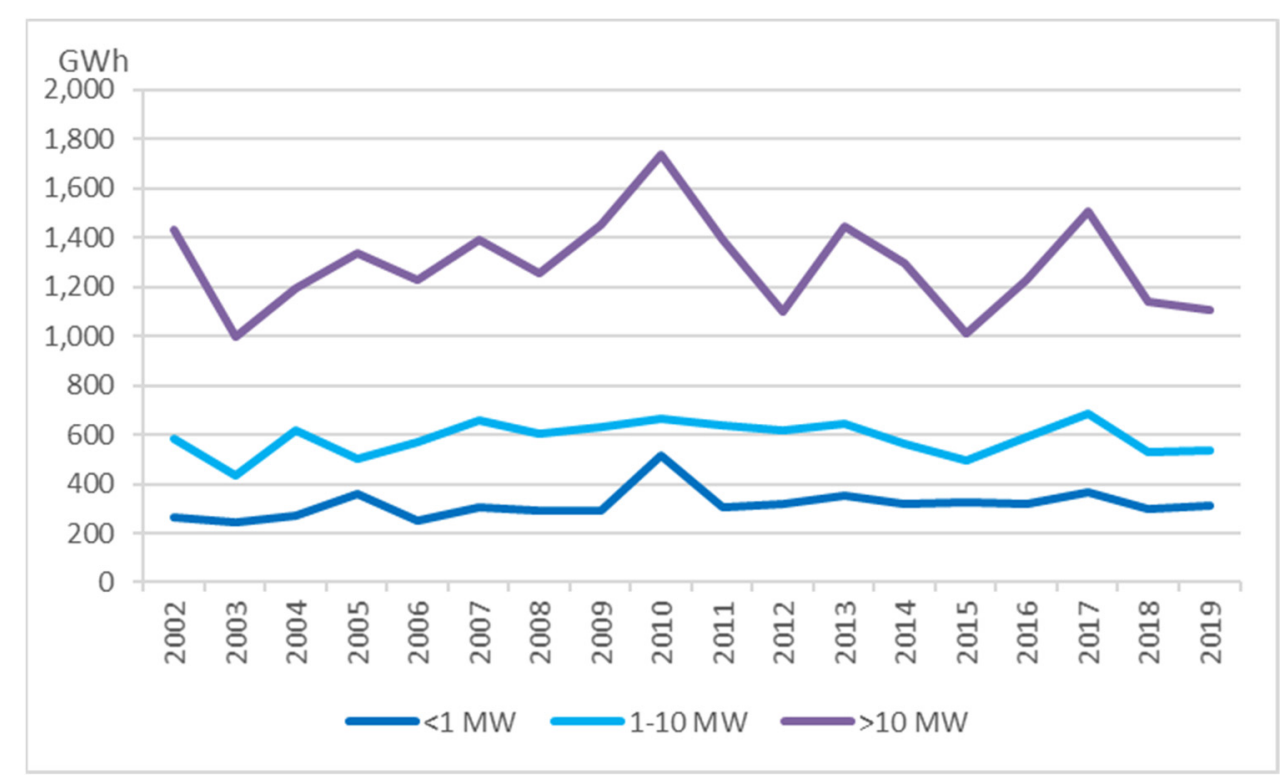

Figure 3. Electricity production in hydropower plants in Poland of various capacities in 2002-2019 (based on data from the Central Statistical Office).

\section{The Impact of Climate Change on the Amount of Energy Produced in Hydropower Plants-A Case Study of the Gwda River}

\subsection{Hydrotechnical Development of the Gwda River}

The Gwda river is located in the north-western part of Poland, it is a tributary of the Noteć river. The total length of the river is $139.95 \mathrm{~km}$, while its catchment area is $4947.27 \mathrm{~km}^{2}$. The Gwda catchment area is a lake catchment basin made of sands and glacial gravel [72]. The forest area accounts for $30 \%$ of the total area, while the lake surface is $2.5 \%$ [73]. Agricultural areas constitute $44.4 \%$ of the Gwda catchment area [74].

The Gwda river is an intensively developed hydrotechnical river (Figure 4). These are mainly small hydropower plants, most of which were built in the years 1905-1937 [75]. The youngest power plant was put into operation in Byszki (the mouth of the Gwda river) in 2012. In 2012, Plecemin Commune Head filed an application for the issuance of conditions for the construction of another barrage on the Gwda river, located in the village of Plecemin, on the river section between SHP Tarnówka and SHP Dobrzyca. The power plant is to be equipped with three Archimedes turbines with a total capacity of $457 \mathrm{~kW}$ with a height of the fall $\mathrm{H}=3.21 \mathrm{~m}$. The investment has not yet been launched. Currently, there are 11 hydropower plants on the Gwda river, located along the entire length of the river (from the source to the mouth): Gołebiewo, Lubnica, Weggorzewo, Łomczewo (Żarki), Podgaje, Jastrowie, Ptusza, Tarnówka, Dobrzyca, Koszyce, and Byszki. 


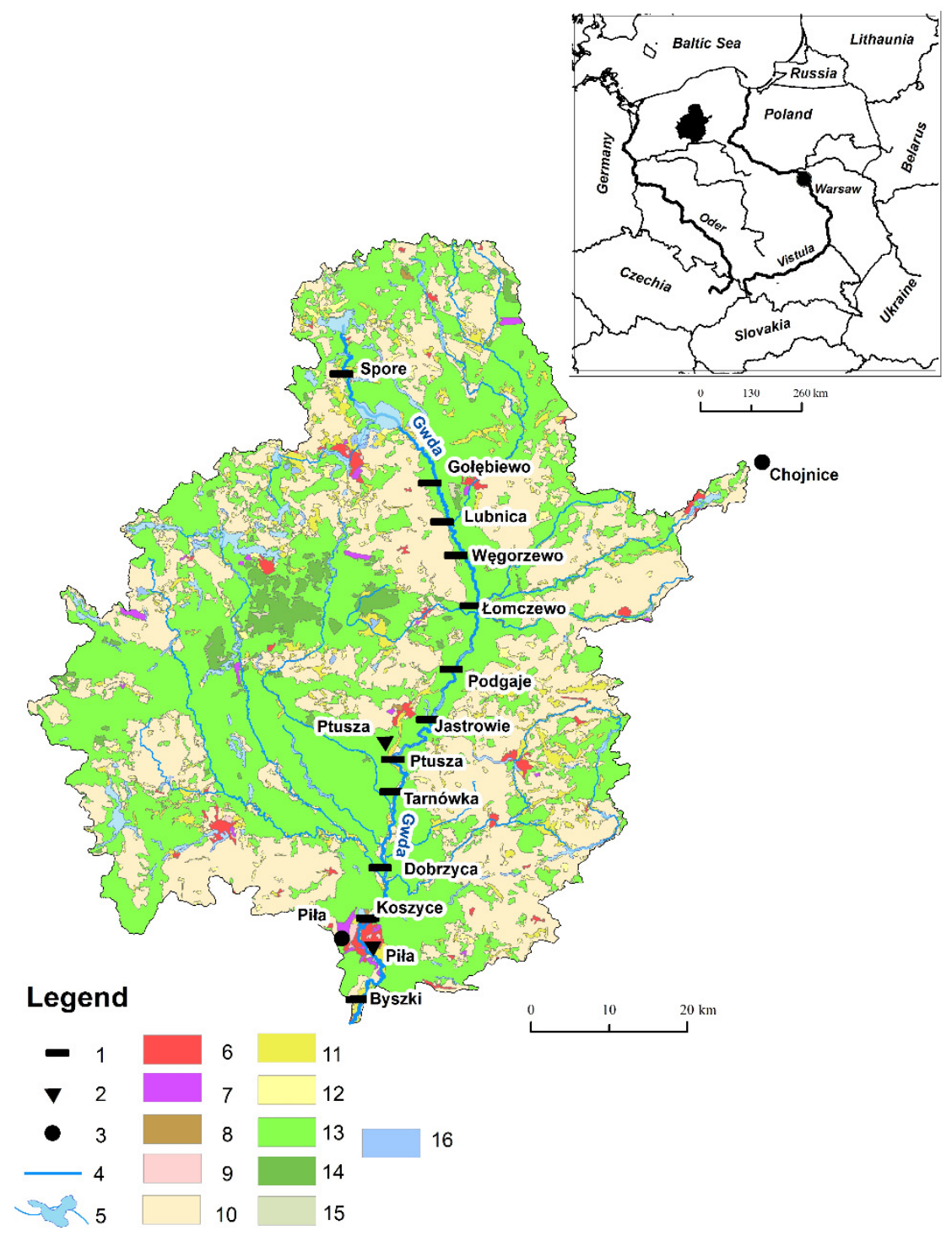

Figure 4. The catchment area of the Gwda river. Explanations: 1—small hydropower plant (SHP), 2hydrometric station, 3-meteorological station, 4-Gwda river, 5-rivers and lakes, 6-urban fabric, 7-industrial, commercial, and transport units, 8-mine, dump, and construction sites, 9-artificial, non-agricultural vegetated areas, 10-arable land, 11-pastures, 12-heterogeneous agricultural areas, 13-forests, 14-scrub and/or herbaceous vegetation associations, 15-open spaces with the little or no vegetation, 16-inland wetlands.

The capacity of the hydroelectric power plants located on the Gwda river ranges from several kilowatts (SHP Gołęiewo) to $2210 \mathrm{~kW}$ (SHP Podgaje). The most powerful hydroelectric power plants on the Gwda river are: Podgaje, Dobrzyca, Jastrowie, Ptusza, and Koszyce (Table 1). Obtaining such high power of these power plants was possible thanks to damming the riverbed with dams, which led to the creation of a network of water reservoirs. The total capacity of water reservoirs at the above-mentioned power plants is about 17 million $\mathrm{m}^{3}$ [76]. 
Table 1. Technical data of selected SHPs located in Gwda Cascade.

\begin{tabular}{ccccc}
\hline SHP & $\begin{array}{c}\text { Installed } \\
\text { Power [kW] }\end{array}$ & $\begin{array}{c}\text { Height of } \\
\text { the Fall [m] }\end{array}$ & $\begin{array}{c}\text { Average Flow } \\
{\left[\mathbf{m}^{\mathbf{3}} \mathbf{s}\right]}\end{array}$ & $\begin{array}{c}\text { Average Electricity } \\
\text { Generation [MWh/Year] }\end{array}$ \\
\hline Podgaje & 2210 & 9.55 & 29.48 & 6519 \\
Jastrowie & 1720 & 7.20 & 30.44 & 6177 \\
Ptusza & 1310 & 6.10 & 27.40 & 4412 \\
Dobrzyca & 1350 & 4.80 & 35.84 & 6370 \\
Koszyce & 1140 & 3.55 & 49.14 & 5500 \\
\hline
\end{tabular}

\subsection{Meteorological and Hydrological Conditions in the Gwda Catchment Area}

The main factor determining the size of the river flows is the meteorological conditions. Precipitation and air temperature are considered to be the main climatic factors driving hydrological change. The amount of river flow, apart from climatic conditions, is influenced by the physiographic features of the catchment area, e.g., soil permeability, topography, land use, and land cover. In addition to natural conditions, the hydrological system of rivers is influenced by the use of water resources in river basins and the modification of the river regime by man. The complexity of the interaction of the above factors makes it extremely difficult to clearly determine which of these factors plays a decisive role. The pressure on water resources is increasing and often leads to a decline in available water resources. In the analyzed multiannual period 1990-2019, a decrease in the annual sums of atmospheric precipitation and an increase in the average annual air temperature were observed (Figures 5 and 6). The highest annual sums of precipitation are recorded in the upper part of the Gwda catchment area, which decrease as the height of the terrain in the lower part of the catchment decreases. In the analyzed multi-year period, there was a slight upward trend in precipitations at the Chojnice station and a slight downward trend at the Piła station. Changes in trends are small, which is due to the location of meteorological stations. Chojnice station is located on a moraine hill (164 m a.s.l)., while Piła station is located on a small height (73.3 m a.s.l.). Data for Piła station are representative for most of the catchment area of the river Gwda. The air temperature recorded at both meteorological stations showed a clear upward trend.

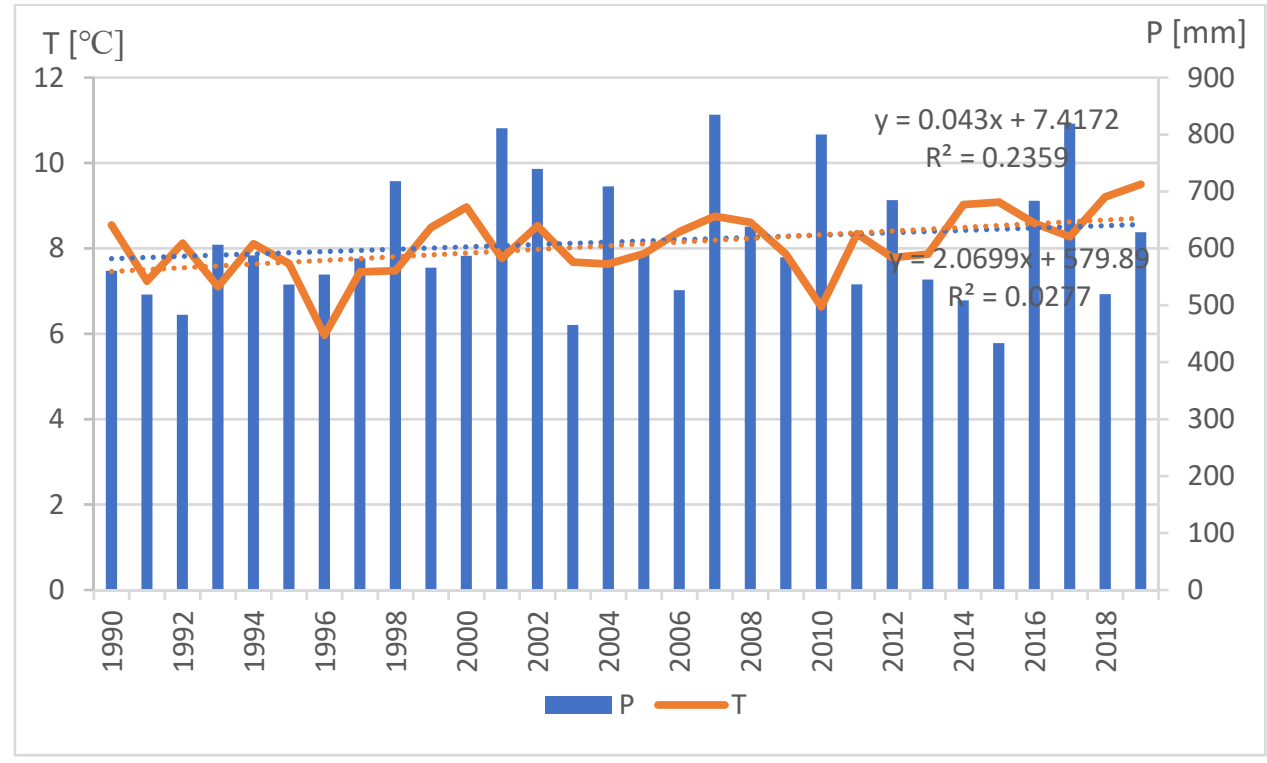

Figure 5. Average air temperature $(\mathrm{T})$ and precipitation $(\mathrm{P})$ during the year at the Chojnice meteorological station in years 1990-2019 (based on data from the Institute of Meteorology and Water Management-National Research Institute). 


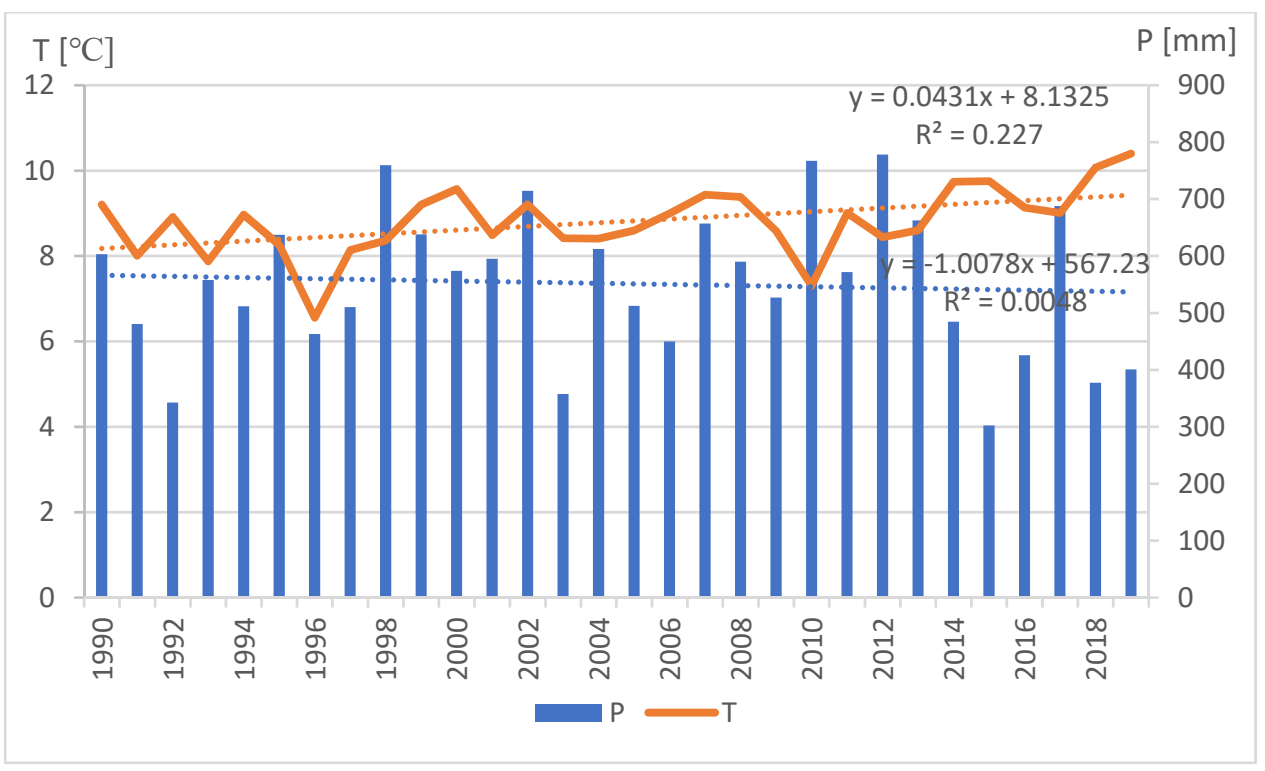

Figure 6. Average air temperature $(\mathrm{T})$ and precipitation $(\mathrm{P})$ during the year at the Piła meteorological station in years 1990-2019 (based on data from the Institute of Meteorology and Water ManagementNational Research Institute).

The hydrological conditions of the Gwda river have been discussed on the basis of the river flows in its estuary, i.e., at the Piła station. The analysis of the flows of this river in the years 1951-2019 showed that the average annual flow was $26.9 \mathrm{~m}^{3} / \mathrm{s}$, which in terms of specific runoff from the catchment area was $5.7 \mathrm{dm}^{3} / \mathrm{s} . \mathrm{km}^{2}$. The maximum flow in this period was $111.0 \mathrm{~m}^{3} / \mathrm{s}$ (1970), while the minimum flow was $8.2 \mathrm{~m}^{3} / \mathrm{s}$ (2015).

In the years 1990-2019, the average annual flows are slightly lower and amount to $26.4 \mathrm{~m}^{3} / \mathrm{s}$, and the maximum and minimum values are, respectively, $79.4 \mathrm{~m}^{3} / \mathrm{s}(2002)$ and $8.2 \mathrm{~m}^{3} / \mathrm{s} \mathrm{(2015)} \mathrm{(Figure} \mathrm{7).} \mathrm{From} \mathrm{the} \mathrm{point} \mathrm{of} \mathrm{view} \mathrm{of} \mathrm{the} \mathrm{energy} \mathrm{use} \mathrm{of} \mathrm{the} \mathrm{river,} \mathrm{an}$ important hydrological parameter is the flow corresponding to the 70th and 95th percentiles of the flow duration curve along with the higher ones, determined on the basis of daily values for the entire multiannual period. The flow with a probability of $70 \%(\mathrm{Q} 70 \%)$ is the limit value for the shallow low flow $\left(21.2 \mathrm{~m}^{3} / \mathrm{s}\right)$, while the flow with a probability of $95 \%$ $(\mathrm{Q} 95 \%)$ is the limit value for the deep low flow $\left(14.9 \mathrm{~m}^{3} / \mathrm{s}\right)$ [77]. Electricity production is limited or impossible due to too-low flows. A comparison of days with flows below Q70\% and Q95\% in 1990-2019 is presented in Figure 8. The number of days with Q70\% flows in this multi-year period shows an upward trend, similar to flows with Q95\%. The highest number of days with flows below Q70\% and Q95\% were recorded in the dry years, and in addition to 1992, when the highest number of days with such flows occurred in recent years, it was also 2014, 2015, 2016, and 2019. 


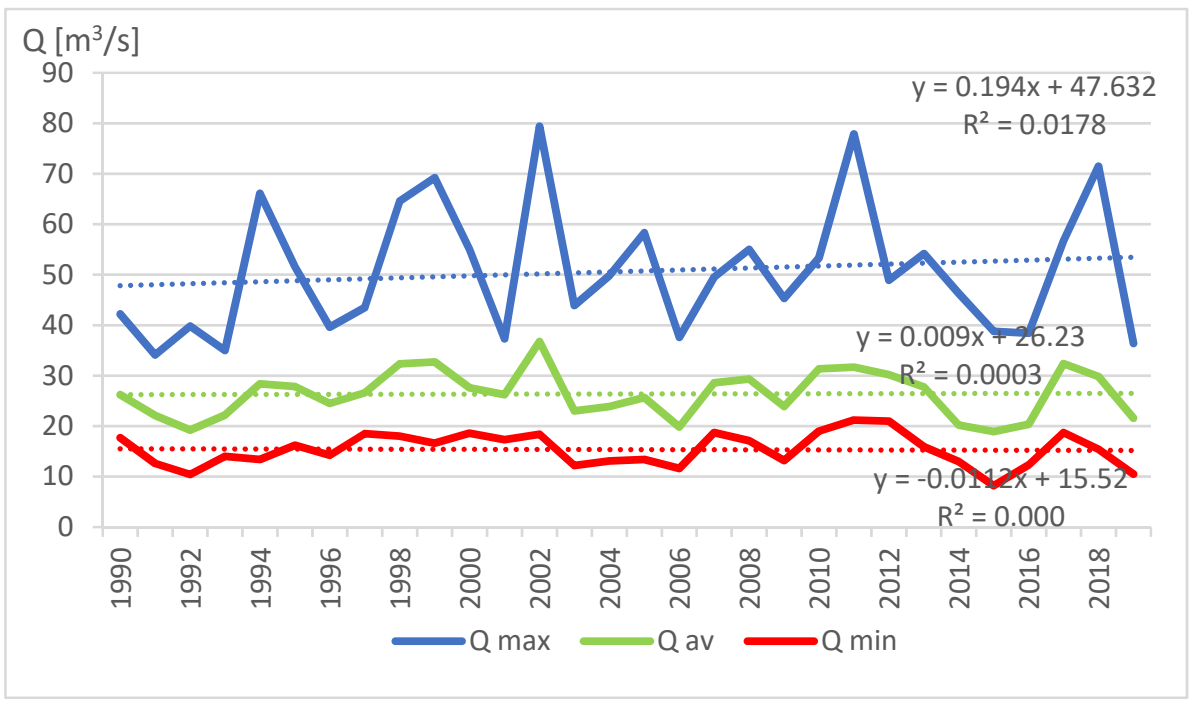

Figure 7. The maximum ( $\mathrm{Q}$ max), average $(\mathrm{Q}$ av), and minimum $(\mathrm{Q}$ min) annual flow of the Gwda river at the Piła hydrometric station in 1990-2019 (based on data from the Institute of Meteorology and Water Management-National Research Institute).

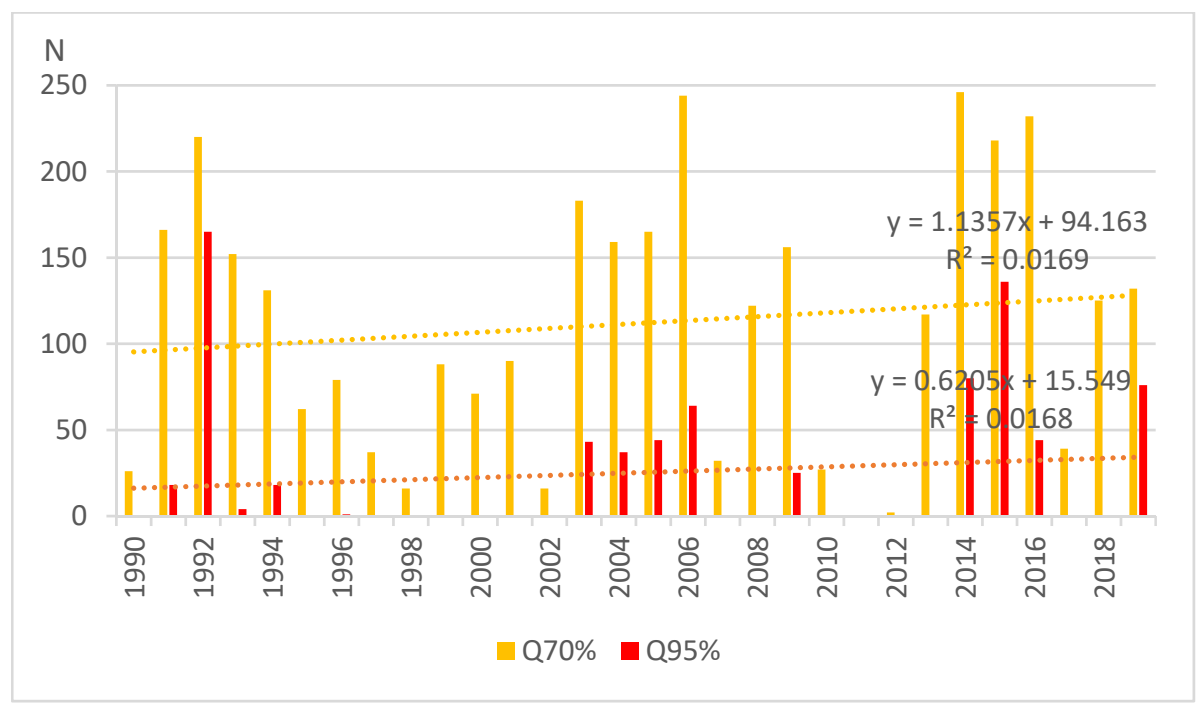

Figure 8. Number of days (N) per year with flows below Q70\% and Q95\% in years 1990-2019 (based on data from the Institute of Meteorology and Water Management-National Research Institute).

The course of low flows in seasonal terms is characterized by large variations throughout the year (Figure 9). The highest values of low flows are recorded in the winter half of the year, i.e., from November to April, and are characterized by the highest amplitude of low flows. The lowest flows occur in the summer half of the year (from May to October), mainly in July. The average number of days with flows below Q70\% is usually from 15 to 20 days in June, July, and August, while with flows below Q95\%, it is from 2 to 6 days in the months from June to December. 


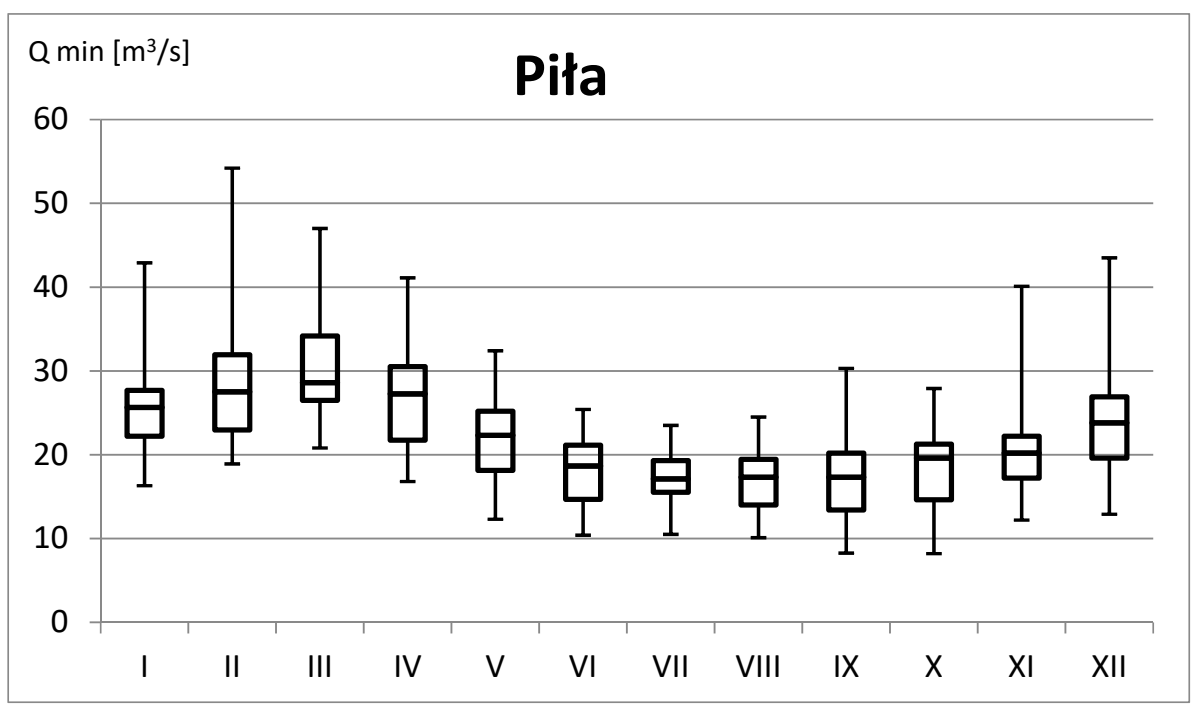

Figure 9. Distribution of low monthly flows of the Gwda river at the Piła hydrometric station during the year (Q min) in 1990-2019 (based on data from the Institute of Meteorology and Water Management-National Research Institute).

\subsection{Correlation between Energy Production and Flow}

First, the correlation between precipitation and flow was analyzed. Calculation shows that there is lower correlation $(r=0.5)$ obtained between precipitation in Chojnice area and water flow in Piła hydrometric station. Correlation between precipitation in Piła area and water flow in Piła is higher $(r=0.76)$. Determination of the statistical significance of Pearson's $r$ correlation coefficient $(\alpha=0.05)$ was based on the value read from the statistical table included in the book by [78].

The analysis of the correlation between energy production and water flow was carried out for the five previously described power plants located in Gwda Cascade. As previously mentioned, the 30-year period of the analysis covering the years 1990-2019 was adopted (Figure 10). The chart shows the average annual flows. Quite large flow fluctuations can be noticed, reaching values from $19.0 \mathrm{~m}^{3} / \mathrm{s}$ (in 1992, 2006, and in 2015) to $36.8 \mathrm{~m}^{3} / \mathrm{s}$ in 2002 . In the analyzed period, the average flow is $26.4 \mathrm{~m}^{3} / \mathrm{s}$ and, in principle, perfectly coincides with the trend line, which is almost horizontal. It may suggest that long-term changes do not apply to the catchment area of the analyzed river.

For the purposes of the analysis, there were two years selected, which were characterized as "dry", with low average flows due to low precipitation levels, two years with average flows, and two years with high average flows, characterized as "wet". The years 1992 and 2006 were classified as dry years, with average annual flows of $19 \mathrm{~m}^{3} / \mathrm{s}$. The years 1997 and 2001 were classified into the group of average years, with average annual flows at the level of $26.0 \mathrm{~m}^{3} / \mathrm{s}$. The years 1999 and 2002 were classified as wet years, with average annual flows of 33 and $36 \mathrm{~m}^{3} / \mathrm{s}$, respectively (Figure 11).

There is a continuing upward trend in the average monthly flows in the winter-spring months (February-May) and a downward trend in the summer months (June-October). However, in some years, these trends are disrupted, e.g., in 2001, in which flows were low in the spring months (at the level of dry years) and in autumn, they were higher than average. In September, they were even higher than in the most abundant in the wettest year, 2002 (Figure 12). 


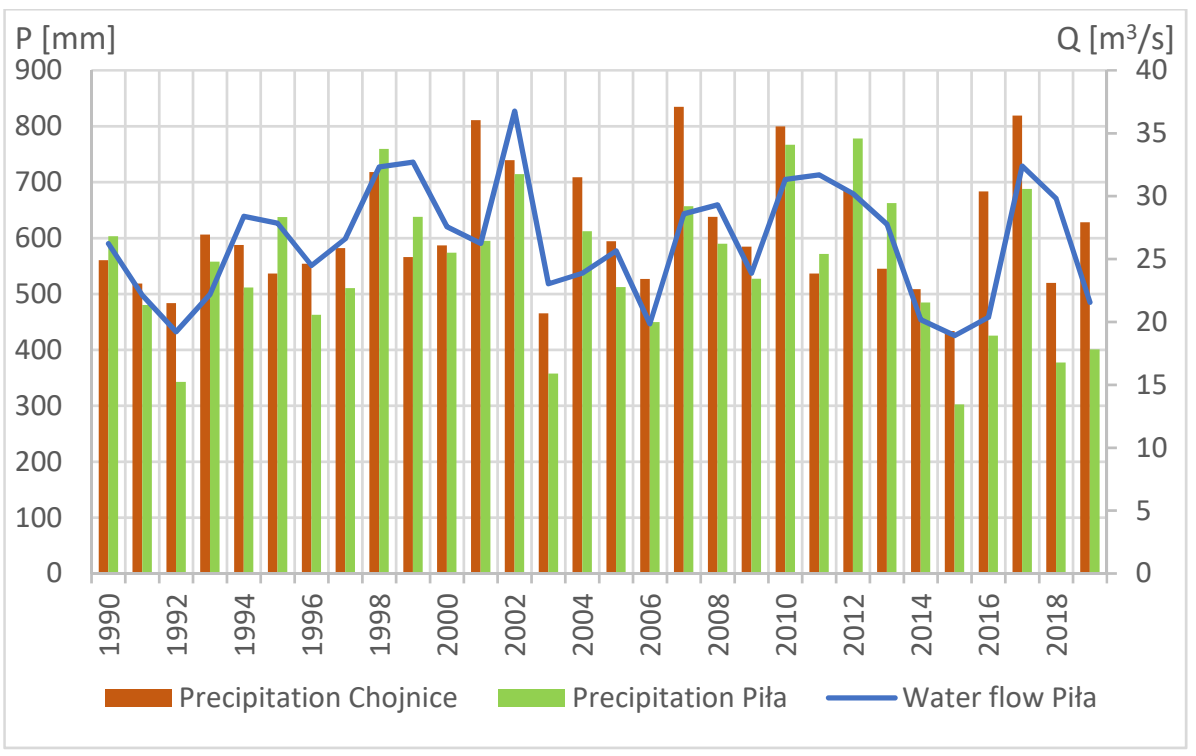

Figure 10. The average annual flow $(\mathrm{Q})$ of the Gwda river in the hydrometric station Piła and annual precipitations (P) in the meteorological stations Chojnice and Piła in 1990-2019 (based on data from the Institute of Meteorology and Water Management-National Research Institute).

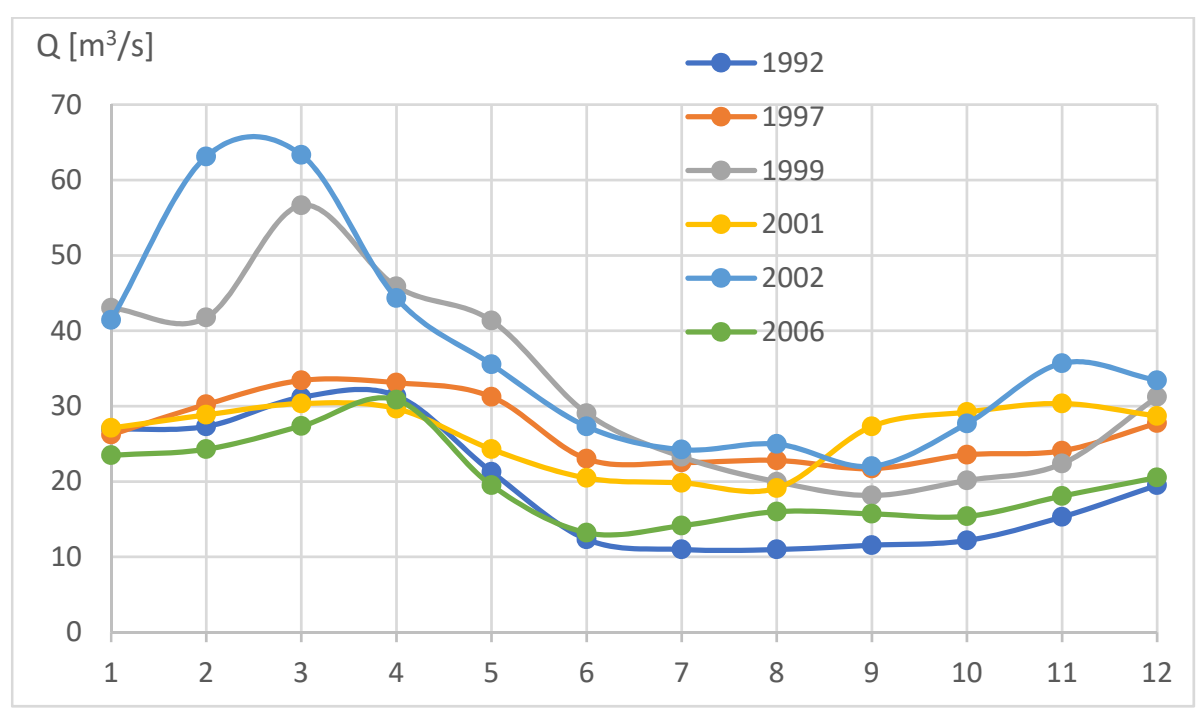

Figure 11. Average monthly flows at the height of Piła in the years characterized as dry (1992 and 2006), normal (1997 and 2001), and wet (1999 and 2002) (based on data from the Institute of Meteorology and Water Management-National Research Institute).

As mentioned earlier, the flows were analyzed in five hydropower plants on the Gwda river, forming the so-called Gwda Cascade. Figure 13 compares the flows through these power plants in dry, average, and wet years. It can be clearly noticed that the flows at the Podgaje, Jastrowie, and Ptusza power plants are almost 50\% lower than at the Dobrzyca and Koszyce power plants. This is mainly due to the smaller catchment area. It may be caused by the tributaries of the Płytnica, Różyca, and Piława rivers, which flow directly into the Dobrzycki Reservoir just above of Dobrzyca SHP.

Figure 13 shows the average annual flows for the selected Gwda Cascade power plants. It can be noticed that in dry years, compared to the average, there is a decrease in flows by about $25 \%$, and in wet years, the increase in flows may even reach approximately $40 \%$.

As not all the water flows through the turbines, especially during flows exceeding the so-called installed water flow, the water is discharged, bypassing the turbines. At 
normal flows, a constant supply over the fish pass is required to enable fish migration. The difference is approximately $3 \%$ in dry years, approximately $4 \%$ in average years, and $7 \%$ in wet years.

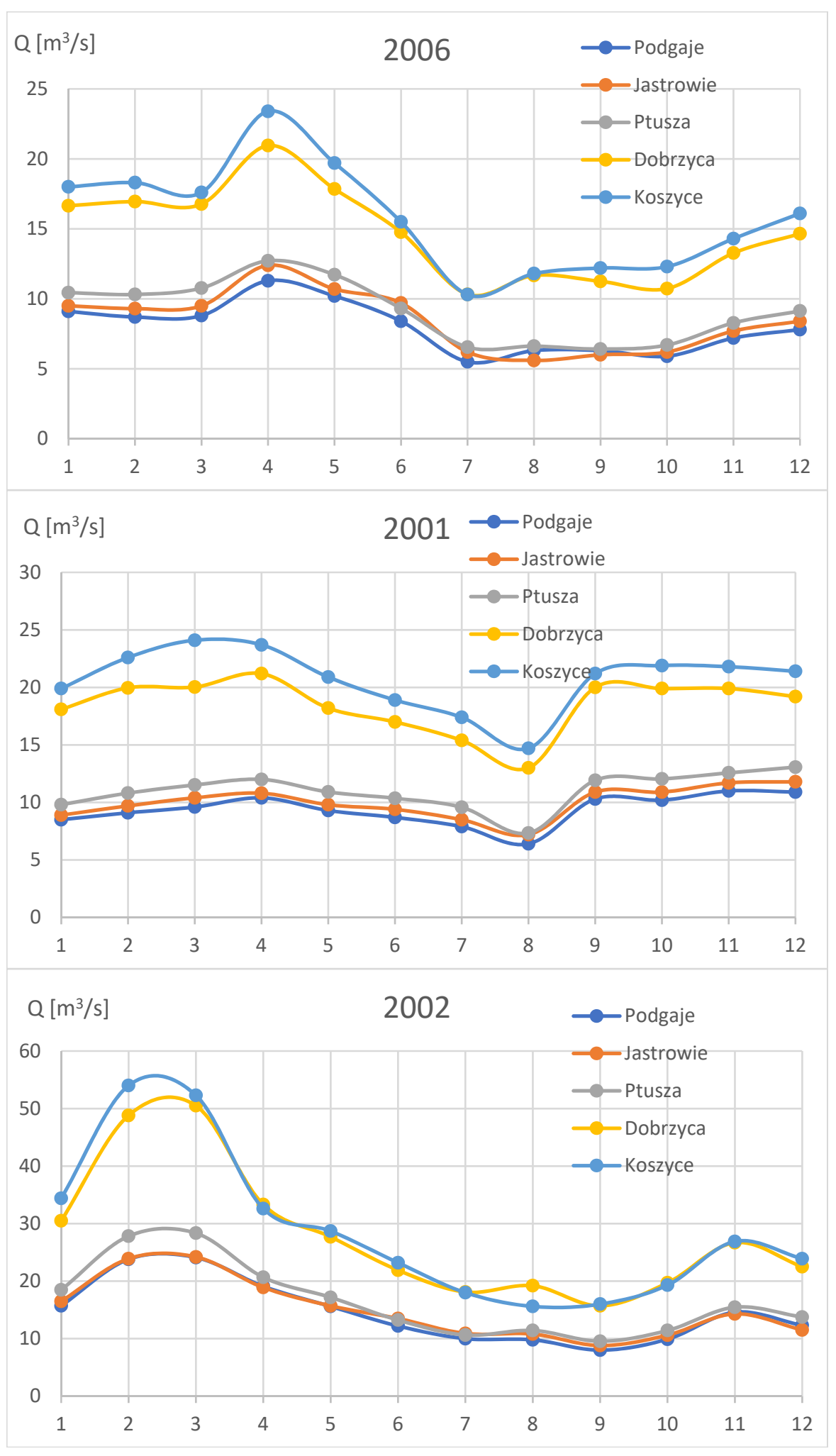

Figure 12. Average monthly flow of the Gwda river by selected small hydropower plants in a dry year (2006), normal year (2001), and wet year (2002) (based on data from the Energy Service Company Jastrowie). 


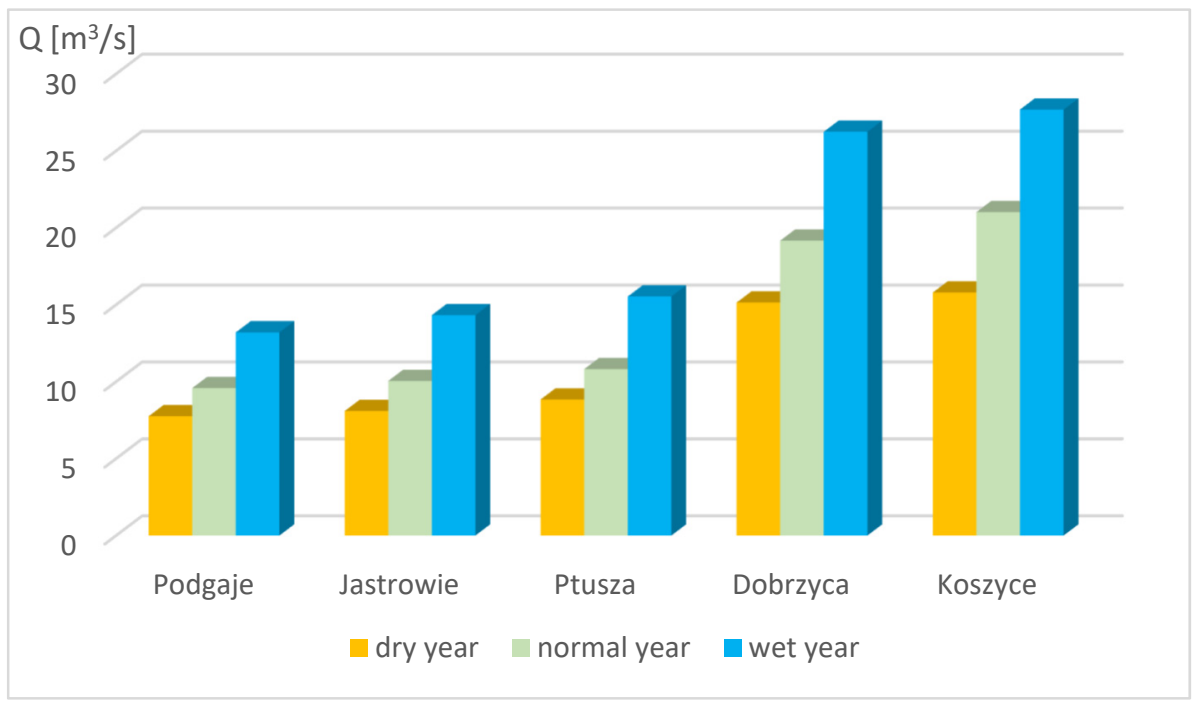

Figure 13. Average annual flows by selected Gwda small hydropower plants in dry, normal, and wet years (based on data from the Energy Service Company Jastrowie).

It is important to know the level of efficiency of every hydropower plant, because it has an influence on the electricity production level. There are little differences between plants as is shown on Figure 14. The lowest efficiency is observed in SHP Ptusza, which may be connected with the fact that it is the oldest hydropower unit in Gwda Cascade.

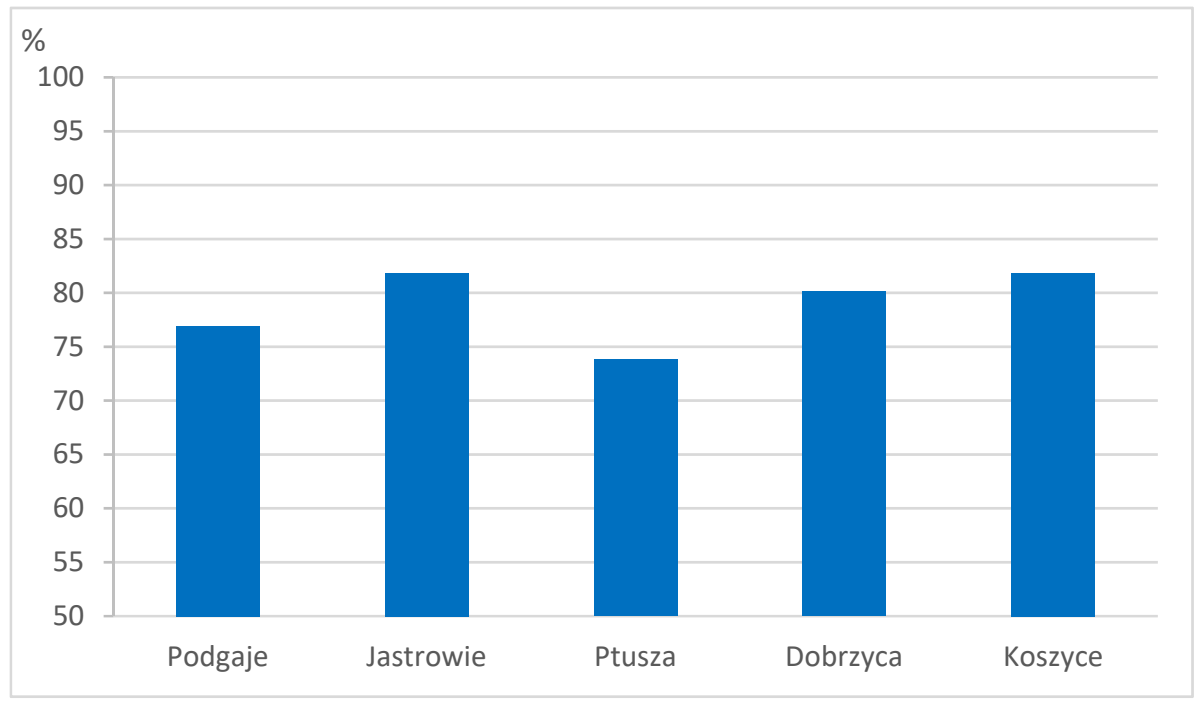

Figure 14. Efficiency of hydropower units in selected small hydropower plants in the Gwda river (based on data from the Energy Service Company Jastrowie).

The flows through the turbine enable the production of electricity. This depends not only on the water flow rate, but also on the height of water damming, and this value is characteristic for each hydroelectric power plant (Table 1). The highest level of damming among the analyzed power plants is at SHP Podgaje. It is almost $10 \mathrm{~m}$. The lowest damming level is at the power plant in Koszyce. It is $3.55 \mathrm{~m}$. Lower damming but higher flow rates mean that all five power plants in the Gwda river cascade show similar average electricity production. The most deviating from this pattern is SHP Ptusza, whose production is almost 30\% lower than that produced by SHP Dobrzyca, Podgaje, and Jastrowie. On the other hand, the power plants in Dobrzyca and Koszyce (lower section of the Gwda river) are less sensitive to changes in the flow rate compared to the power plants located in the upper section of the Gwda river (Podgaje, Jastrowie, Ptusza). The differences in production 
between the wet and dry season amount to approximately $40-45 \%$ in power plants in the upper section of the river, and less than $30 \%$ in the lower section. The comparison of the production level in selected Gwda Cascade power plants for different water supply levels is shown in Figure 15.

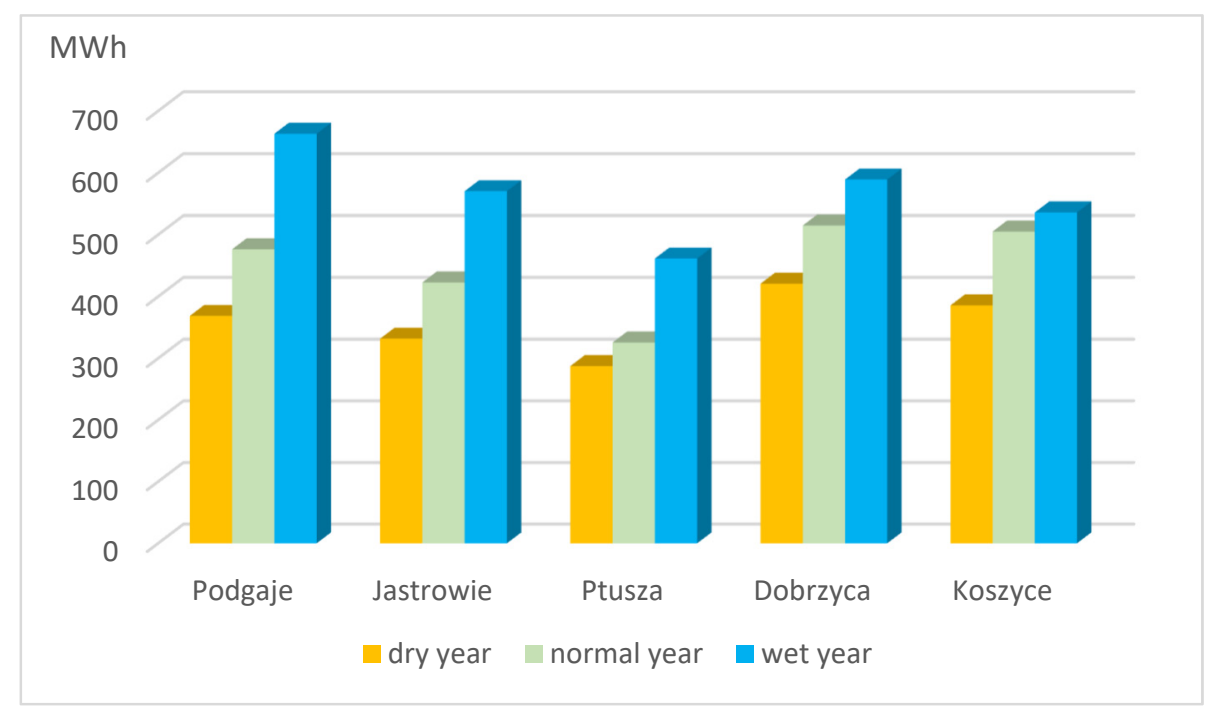

Figure 15. Average annual electricity production (MWh) by selected Gwda small hydropower plants in dry, normal, and wet years with different water supply levels (based on data from the Energy Service Company Jastrowie).

The level of electricity production depends on the installed capacity of the equipment used in the hydropower plant and different water supply levels. Two breakdowns of production in relation to average and maximum production are presented Figures 16 and 17.

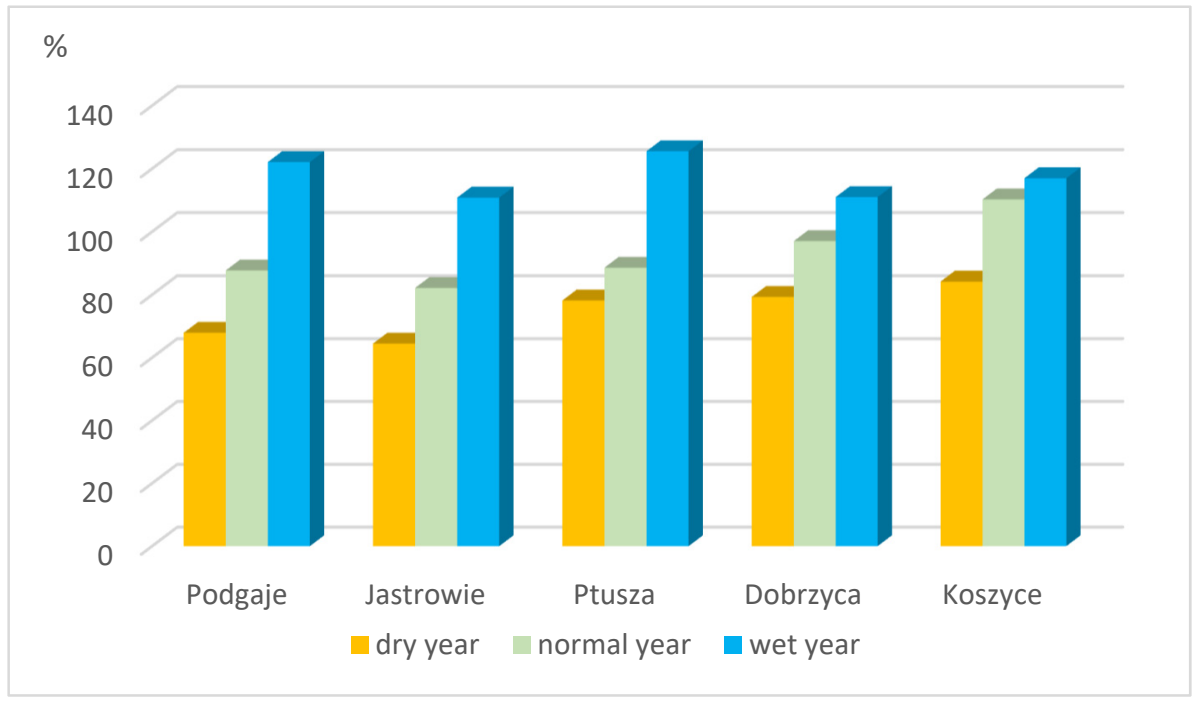

Figure 16. Average annual electricity production (MWh) by selected Gwda small hydropower plants in dry, normal, and wet years with different water supply levels in relation to the average production (based on data from the Energy Service Company Jastrowie). 


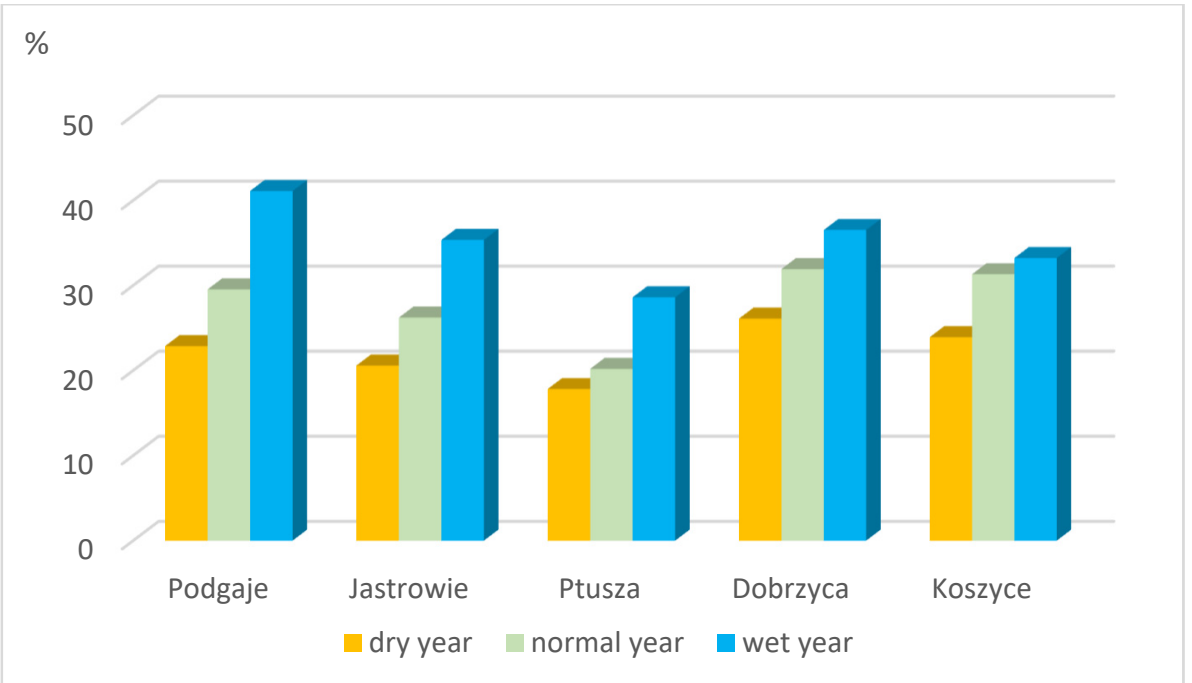

Figure 17. Electricity production in selected power plants at different water supply levels in relation to the maximum production (based on data from the Energy Service Company Jastrowie).

It can be seen that in the years with the average flow, the level is close to the average production value in the multiannual period, with slightly lower values at $90 \%$ for power plants located upstream of the Gwda river and at $100 \%$ for the hydropower plants located downstream. This trend repeats with slightly greater intensity at low flows. Hydropower plants Podgaje and Jastrowie work then at the level of less than $70 \%$ in relation to the average production, and hydropower plants Dobrzyca and Koszyce at the level of $80 \%$. This trend is reversed during high flows, when power plants in the upper course produce over $20 \%$ more energy and power plants in the lower course-10-15\% more.

It turns out that in the years with an average level of water supply, energy production is maintained at the level of 30\% (SHP Ptusza-20\%). In the years with a lower level of water supply, the level of production in relation to the capacity drops to approximately $20 \%$. In the years with a high level of power supply, the utilization of the potential of hydropower plants located in the Gwda Cascade is at the level of 30-35\% (SHP Podgaje$41 \%$ ). This means that, probably in anticipation of years with extremely high flows (flood waves), power plants are clearly oversized. Another reason may be the lack of orders for electricity from the management company or from the National Energy System (NPS).

In conclusion, it should be stated that there is a significant correlation between the level of precipitation related to the level of water supply (discussed in Section 5.3) and between water supply and electricity production (showed on Figure 18). It is not unequivocal. There is a clear trend towards better use of high water flows in high damming power plants upstream of the Gwda river. On the other hand, during low flows, these power plants cope worse- the reduction in production can be as high as $40 \%$. Power plants located in the lower reaches of the Gwda river, with lower damming but higher flows, behave more stably, showing changes between dry and wet years at the level of $\pm 20 \%$. In general, the level of use of Gwda's water resources is not high and amounts to a maximum of $40 \%$. The technical condition of the power plant may also affect the level of production. The charts show that SHP Ptusza is in the weakest condition. The Dobrzyca and Koszyce power plants were undergoing modernization. SHP Dobrzyca, in 2006, had a thorough replacement of old Francis turbines with modern Kaplan turbines. 


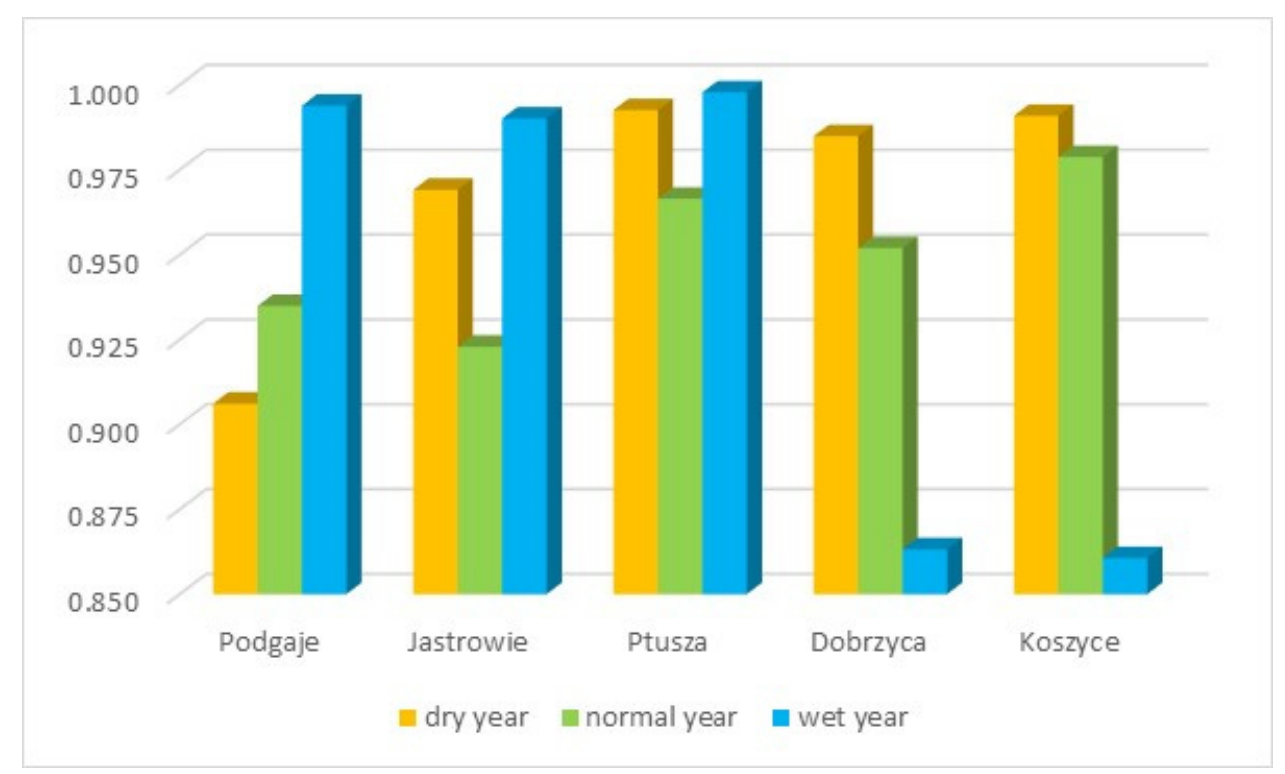

Figure 18. Linear correlation between water flow and energy production in selected power plants at different feed levels (based on data from the Energy Service Company Jastrowie). Determination of the statistical significance of Pearson's $r$ correlation coefficient $(\alpha=0.05)$ was based on the value read from the statistical table included in the book by [78].

The use of a cascade, in turn, allows to significantly increase the intensity of water use. In the case of Gwda, the sum of the power of individual stages brings this river closer to the group of large hydropower plants. The total installed capacity of only the five analyzed power plants is $7.8 \mathrm{MW}$.

\section{Discussion and Conclusions}

Poland, as a member state of the European Union, has committed to achieving $15 \%$ in 2020 and $20 \%$ of energy from renewable sources by the end of 2030. The target set for 2020 has not been achieved by Poland, and therefore, there is a chance that achieving this target in 2030 will also be at risk.

In line with the adopted energy strategy [46], the use of wind and solar energy will play a key role in achieving the target in the power sector by 2040. Both sources are characterized by high variability of their output power and very low availability [69]. Many authors point out that renewable energy sources largely depend on the environmental resources of individual countries and investment costs [79]. An example is hydropower, which, despite the known technology, requires a comprehensive analysis of the impact of social, economic, environmental, and climate change factors. An additional factor that should be taken into account in the analysis is the use of the available hydropower potential, i.e., economic profitability and technical feasibility [80].

The decrease in the share of electricity production from hydropower plants in Poland is a good example of the lack of major investments related to the use of the existing hydropower potential. The construction of large hydropower plants (above $10 \mathrm{MW}$ ) after 2000, in principle, involves single facilities. There is also little interest in building new small hydropower plants (below $10 \mathrm{MW}$ ). A small amount of electricity produced from hydropower plants may result, in addition to changing hydrological conditions (floods or droughts), from an outdated installation that is not able to use the existing energy potential of the river. Many small hydropower plants operate on the basis of water turbines that have been in operation for several dozen years. The existing support system for small hydropower plants in Poland is insufficient to finance a thorough modernization of the existing hydropower plants. In the first place, modernizations are carried out for large, state-owned facilities. 
There are currently no major investments in hydropower renewable energy sources in Poland, unlike in the countries of south-eastern Europe [81-83]. Much greater dynamics are observed in the use of wind and solar energy. After all, hydropower requires slightly larger initial investments, but it can be operated efficiently without major investment outlays for a period of 50-100 years. The durability of devices used in wind and photovoltaic energy is not so high, therefore, the renovation of devices must be carried out much more often (10-20 years). For the sustainable development of the power industry based on renewable energy sources, it is necessary to invest in both hydro, wind, and solar energy, because each of them is characterized by a different sensitivity to weather conditions.

Summing up, it should be stated that the increase in electricity production generated in small hydropower plants is possible by co-financing the modernization of existing facilities as part of the energy policy pursued. A similar situation may also apply to other European Union countries where the return on investment is very long.

Author Contributions: Conceptualization, K.K.-W. and L.S.; methodology, K.K.-W. and L.S.; formal analysis, K.K.-W. and L.S.; investigation, K.K.-W. and L.S.; resources, K.K.-W.; data curation, K.K.-W.; writing-original draft preparation, K.K.-W. and L.S.; writing-review K.K.-W. and L.S.; project administration, K.K.-W.; funding acquisition, K.K.-W. All authors have read and agreed to the published version of the manuscript.

Funding: The APC was funded by Faculty of Earth Sciences and Spatial Management, Nicolaus Copernicus University.

Institutional Review Board Statement: Not applicable.

Informed Consent Statement: Not applicable.

Data Availability Statement: Not applicable.

Conflicts of Interest: The authors declare no conflict of interest.

\section{References}

1. European Energy Agency. 2021. Available online: https://www.eea.europa.eu/pl/themes/climate/about-climate-change (accessed on 10 April 2021).

2. IPCC 2013. Climate Change 2013: The Physical Science Basis; Contribution of Working Group I to the Fifth Assessment Report of the Intergovernmental Panel on Climate Change; Stocker, T.F., Qin, D., Plattner, G.K., Tignor, M., Allen, S.K., Boschung, J., Nauels, A., Xia, Y., Bex, V., Midgley, P.M., Eds.; Cambridge University Press: Cambridge, UK; New York, NY, USA, 2013.

3. Falchetta, G.; Gernaat, D.E.; Hunt, J.; Sterl, S. Hydropower dependency and climate change in sub-Saharan Africa: A nexus framework and evidence-based review. J. Clean. Prod. 2019, 231, 1399-1417. [CrossRef]

4. Hamududu, B.H.; Killingtveit, A. Hydropower Production in Future Climate Scenarios; the Case for the Zambezi River. Energies 2016, 9, 502. [CrossRef]

5. Xu, Y.; Zhou, B.-T.; Wu, J.; Han, Z.-Y.; Zhang, Y.-X.; Wu, J. Asian climate change under $1.5-4{ }^{\circ} \mathrm{C}$ warming targets. Adv. Clim. Chang. Res. 2017, 8, 99-107. [CrossRef]

6. Head, L.; Adams, M.; McGregor, H.; Toole, S. Climate change and Australia. Wiley Interdiscip. Rev. Clim. Chang. 2013, 5, 175-197. [CrossRef]

7. Jacob, D.; Kotova, L.; Teichmann, C.; Sobolowski, S.P.; Vautard, R.; Donnelly, C.; Koutroulis, A.G.; Grillakis, M.G.; Tsanis, I.K.; Damm, A.; et al. Climate Impacts in Europe Under $+1.5^{\circ} \mathrm{C}$ Global Warming. Earth's Futur. 2018, 6, 264-285. [CrossRef]

8. Roudier, P.; Andersson, J.C.M.; Donnelly, C.; Feyen, L.; Greuell, W.; Ludwig, F. Projections of future floods and hydrological droughts in Europe under a $+2{ }^{\circ} \mathrm{C}$ global warming. Clim. Chang. 2015, 135, 341-355. [CrossRef]

9. Hamududu, B.; Killingtveit, A. Assessing Climate Change Impacts on Global Hydropower. Energies 2012, 5, 305-322. [CrossRef]

10. Van Vliet, M.T.H.; Wiberg, D.; LeDuc, S.; Riahi, K. Power-generation system vulnerability and adaptation to changes in climate and water resources. Nat. Clim. Chang. 2016, 6, 375-380. [CrossRef]

11. Van Vliet, M.T.H.; Sheffield, J.; Wiberg, D.; Wood, E.F. Impacts of recent drought and warm years on water resources and electricity supply worldwide. Environ. Res. Lett. 2016, 11, 124021. [CrossRef]

12. Hoes, O.; Meijer, L.J.J.; Van Der Ent, R.J.; Van De Giesen, N.C. Systematic high-resolution assessment of global hydropower potential. PLoS ONE 2017, 12, e0171844. [CrossRef]

13. Carvajal, P.E.; Li, F.G.; Soria, R.; Cronin, J.; Anandarajah, G.; Mulugetta, Y. Large hydropower, decarbonisation and climate change uncertainty: Modelling power sector pathways for Ecuador. Energy Strategy Rev. 2019, 23, 86-99. [CrossRef]

14. Vaidya, R.A.; Molden, D.J.; Shrestha, A.B.; Wagle, N.; Tortajada, C. The role of hydropower in South Asia's energy future. Int. J. Water Resour. Dev. 2021, 37, 367-391. [CrossRef] 
15. Caceres, A.L.; Jaramillo, P.; Matthews, H.S.; Samaras, C.; Nijssen, B. Hydropower under climate uncertainty: Characterizing the usable capacity of Brazilian, Colombian and Peruvian power plants under climate scenarios. Energy Sustain. Dev. 2021, 61, 217-229. [CrossRef]

16. Yalew, S.G.; van Vliet, M.T.H.; Gernaat, D.E.H.J.; Ludwig, F.; Miara, A.; Park, C.; Byers, E.; De Cian, E.; Piontek, F.; Iyer, G.; et al. Impacts of climate change on energy systems in global and regional scenarios. Nat. Energy 2020, 5, 794-802. [CrossRef]

17. Seljom, P.; Rosenberg, E.; Fidje, A.; Haugen, J.E.; Meir, M.; Rekstad, J.; Jarlset, T. Modelling the effects of climate change on the energy system-A case study of Norway. Energy Policy 2011, 39, 7310-7321. [CrossRef]

18. Lobanova, A.; Koch, H.; Liersch, S.; Hattermann, F.F.; Krysanova, V. Impacts of changing climate on the hydrology and hydropower production of the Tagus River basin. Hydrol. Process. 2016, 30, 5039-5052. [CrossRef]

19. Teotónio, C.; Fortes, P.; Roebeling, P.; Rodriguez, M.; Robaina-Alves, M. Assessing the impacts of climate change on hydropower generation and the power sector in Portugal: A partial equilibrium approach. Renew. Sustain. Energy Rev. 2017, 74, 788-799. [CrossRef]

20. Lucena, A.F.; Hejazi, M.; Vasquez-Arroyo, E.; Turner, S.; Köberle, A.C.; Daenzer, K.; Rochedo, P.R.; Kober, T.; Cai, Y.; Beach, R.H.; et al. Interactions between climate change mitigation and adaptation: The case of hydropower in Brazil. Energy 2018, 164, 1161-1177. [CrossRef]

21. De Jong, P.; Tanajura, C.A.S.; Sánchez, A.S.; Dargaville, R.; Kiperstok, A.; Torres, E.A. Hydroelectric production from Brazil's São Francisco River could cease due to climate change and inter-annual variability. Sci. Total. Environ. 2018, 634, 1540-1553. [CrossRef] [PubMed]

22. Van Vliet, M.; van Beek, L.; Eisner, S.; Flörke, M.; Wada, Y.; Bierkens, M. Multi-model assessment of global hydropower and cooling water discharge potential under climate change. Glob. Environ. Chang. 2016, 40, 156-170. [CrossRef]

23. Turner, S.W.D.; Ng, J.Y.; Galelli, S. Examining global electricity supply vulnerability to climate change using a high-fidelity hydropower dam model. Sci Total Environ 2017, 590-591, 663-675. [CrossRef]

24. De Jong, P.; Barreto, T.B.; Tanajura, C.; Oliveira-Esquerre, K.P.; Kiperstok, A.; Torres, E.A. The Impact of Regional Climate Change on Hydroelectric Resources in South America. Renew. Energy 2021. [CrossRef]

25. Arango-Aramburo, S.; Turner, S.W.; Daenzer, K.; Ríos-Ocampo, J.P.; Hejazi, M.I.; Kober, T.; Álvarez-Espinosa, A.C.; RomeroOtalora, G.D.; van der Zwaan, B. Climate impacts on hydropower in Colombia: A multi-model assessment of power sector adaptation pathways. Energy Policy 2019, 128, 179-188. [CrossRef]

26. Ali, S.A.; Aadhar, S.; Shah, H.L.; Mishra, V. Projected Increase in Hydropower Production in India under Climate Change. Sci. Rep. 2018, 8, 1-12. [CrossRef] [PubMed]

27. Piniewski, M.; Meresa, H.K.; Romanowicz, R.; Osuch, M.; Szcześniak, M.; Kardel, I.; Okruszko, T.; Mezghani, A.; Kundzewicz, Z.W. What can we learn from the projections of changes of flow patterns? Results from Polish case studies. Acta Geophys. 2017, 65, 809-827. [CrossRef]

28. Forzieri, G.; Bianchi, A.; Silva, F.B.E.; Herrera, M.A.M.; Leblois, A.; Lavalle, C.; Aerts, J.C.; Feyen, L. Escalating impacts of climate extremes on critical infrastructures in Europe. Glob. Environ. Chang. 2018, 48, 97-107. [CrossRef] [PubMed]

29. Cronin, J.; Anandarajah, G.; Dessens, O. Climate change impacts on the energy system: A review of trends and gaps. Clim. Chang. 2018, 151, 79-93. [CrossRef]

30. Magagna, D.; Hidalgo González, I.; Bidoglio, G.; Peteves, S.; Adamovic, M.; Bisselink, B.; De Felice, M.; De Roo, A.; Dorati, C.; Ganora, D.; et al. Water-Energy Nexus in Europe; Publications Office of the European Union: Luxembourg, 2019; ISBN 978-92-76-03385-1. [CrossRef]

31. Kundzewicz, Z.W. Zmiany klimatu, ich przyczyny i skutki-Możliwości przeciwdziałania i adaptacji. Studia BAS 2012, 1, 9-30.

32. Pacesila, M.; Burcea, S.G.; Colesca, S.E. Analysis of renewable energies in European Union. Renew. Sustain. Energy Rev. 2016, 56, 156-170. [CrossRef]

33. Simionescu, M.; Strielkowski, W.; Tvaronavičienè, M. Renewable Energy in Final Energy Consumption and Income in the EU-28 Countries. Energies 2020, 13, 2280. [CrossRef]

34. Central Statistical Office (CSO). Available online: http:/ / stat.gov.pl/ (accessed on 10 April 2021).

35. Energy Regulatory Office (ERO). Available online: https:/ /www.ure.gov.pl/ (accessed on 10 April 2021).

36. Eurostat. 2021. Available online: https://ec.europa.eu/eurostat/statistics-explained/index.php/Renewable_energy_statistics\# Share_of_renewable_energy_more_than_doubled_between_2004_and_2019 (accessed on 15 April 2021).

37. Directive 2001/80/EC of 23 October 2001 on the Limitation of Emissions of Certain Pollutants into the Air from Large Combustion Plants. Available online: https:/ / eur-lex.europa.eu/legal-content/EN/TXT/?uri=uriserv:OJ.L_.2001.309.01.0001.01.ENG (accessed on 10 April 2021).

38. Directive 2009/28/EC of the European Parliament and of the Council of 23 April 2009 on the Promotion of the Use of Energy from Renewable Sources and Amending and Subsequently Repealing Directives 2001/77/EC and 2003/30/EC. Available online: https:/ / eur-lex.europa.eu/eli/dir/2009/28/oj (accessed on 10 April 2021).

39. European Environment Agency. 2021. Available online: https://www.eea.europa.eu/pl/sygna142y/sygnaly-2017/artykuly/ energia-a-zmiany-klimatu (accessed on 20 April 2021).

40. Directive (EU) 2018/2001 of the European Parliament and of the Council of 11 December 2018 on the Promotion of the Use of Energy from Renewable Sources. Available online: https: / eur-lex.europa.eu/legal-content/EN/TXT/PDF/?uri=CELEX: 32018L2001\&from=fr (accessed on 10 April 2021). 
41. Decision No 406/2009/EC of the European Parliament and of the Council of 23 April 2009 on the Effort of Member States to Reduce their Greenhouse Gas Emissions to Meet the Community's Greenhouse Gas Emission Reduction Commitments up to 2020. Available online: https:/ / ec.europa.eu/clima/policies/strategies/2020_en\#tab-0-1 (accessed on 15 April 2021).

42. The European Power Sector in 2020. 2021. Available online: https://ember-climate.org/wp-content/uploads/2021/01/ReportEuropean-Power-Sector-in-2020.pdf (accessed on 15 April 2021).

43. Ligus, M.; Peternek, P. The Sustainable Energy Development Index-An Application for European Union Member States. Energies 2021, 14, 1117. [CrossRef]

44. Polityka Energetyczna Polski do 2030 r., Warszawa 10 listopada 2009. Available online: https://www.pigeor.pl/media/js/ kcfinder/upload/files/Polityka-energetyczna-Polski-do-2030r.pdf (accessed on 15 April 2021).

45. Strategia “Bezpieczeństwo Energetyczne i Środowisko-Perspektywa do 2020 r.", Warszawa, kwiecień 2014. Available online: http:/ / kigeit.org.pl/FTP/PRCIP/Literatura/008_3_Strategia_Bezpieczenstwo_Energetyczne_i_Srodowisko_2020.pdf (accessed on 20 April 2021).

46. Polityka Energetyczna Polski do 2040 r. Warszawa 2021. Obwieszczenie Ministra Klimatu i Środowiska z Dnia 2 Marca 2021r. w Sprawie Polityki Energetycznej Państwa do 2040 r. Available online: https:/ / www.dziennikustaw.gov.pl/M2021000026401.pdf (accessed on 15 April 2021).

47. Kubiak-Wójcicka, K. Variability of Air Temperature, Precipitation and Outflows in the Vistula Basin (Poland). Resources 2020, 9 , 103. [CrossRef]

48. Kubiak-Wójcicka, K. Assessment of Water Resources in Poland. Soils Sediments 2021, 15-34. [CrossRef]

49. Netzband, A.; Reincke, H.; Bergemann, M. A Case Study for the Ecological and Economical Chain of Sediments. Soils Sediments 2002, 2, 112-116. [CrossRef]

50. Stagl, J.C.; Hattermann, F.F. Impacts of Climate Change on the Hydrological Regime of the Danube River and Its Tributaries Using an Ensemble of Climate Scenarios. Water 2015, 7, 6139-6172. [CrossRef]

51. Kubiak-Wójcicka, K.; Machula, S. Influence of Climate Changes on the State of Water Resources in Poland and Their Usage. Geoscience 2020, 10, 312. [CrossRef]

52. Kosiński, J.; Zdulski, W. Hydropower potential of the Vistula. Acta Energetica 2013, 2, 38-47. [CrossRef]

53. Hoffmann, M. Present State and Prospects of Development of Water-Power Engineering in Poland with Special Regard Paid to Demand for Water Turbines; Prace Instytutu Maszyn Przepływowych PAN, 90-91; Państwowe Wydawnictwo Naukowe: Warsaw, Poland, 1989; pp. 51-60.

54. Kubiak-Wójcicka, K.; Szczęch, L. Exploitation of Rivers in Poland for Electricity Production-Current Condition and Perspectives for Development. In Management in Water Resources in Poland; Zelenakova, M., Kubiak-Wójcicka, K., Negm, A.M., Eds.; 2021; pp. 327-355. [CrossRef]

55. Bódis, K.; Monforti, F.; Szabó, S. Could Europe have more mini hydro sites? A suitability analysis based on continentally harmonized geographical and hydrological data. Renew. Sustain. Energy Rev. 2014, 37, 794-808. [CrossRef]

56. Ankiersztejn, I. The Lower Vistula Cascade. Acta Energetica 2013, 3, 70-74. [CrossRef]

57. Szydłowski, M.; Gasiorowski, D.; Zima, P.; Hakiel, J.; Szymkiewicz, R. Hydropower potential of the lower Vistula. Acta Energetica 2015, 18-25. [CrossRef]

58. Dembińska, M. Przetwórstwo Zbożowe w Polsce Średniowiecznej (X-XIV w.); Zakład Narodowy im. Ossolińskich: Wrocław, Poland, 1970.

59. Baranowski, B. Polskie Mtynarstwo; Ossolineum: Warsaw, Poland, 1977.

60. Kaniecki, A.; Brychcy, D. Średniowieczne młyny wodne i ich wpływ na przemiany stosunków wodnych na przykładzie zlewni Obry Skwierzyńskiej. Bad. Fizjogr. Pol. Zach. 2010, 61, 145-156. [CrossRef]

61. Hoffmann, M. Małe Elektrownie Wodne-Poradnik. Small Hydropower-Handbook, 2nd ed.; Towarzystwo Rozwoju Małych Elektrowni Wodnych: Gdansk, Poland, 1992.

62. Zimny, J.; Michalak, P.; Bielik, S.; Szczotka, K. Directions in development of hydropower in the world, in Europe and Poland in the period 1995-2011. Renew. Sustain. Energy Rev. 2013, 21, 117-130. [CrossRef]

63. Granatowicz, J. The next dam on the Vistula River below Włocławek. Acta Energetica 2013, 3, 99-105. [CrossRef]

64. Habel, M.; Mechkin, K.; Podgorska, K.; Saunes, M.; Babiński, Z.; Chalov, S.; Absalon, D.; Podgórski, Z.; Obolewski, K. Dam and reservoir removal projects: A mix of social-ecological trends and cost-cutting attitudes. Sci. Rep. 2020, 10, 1-16. [CrossRef] [PubMed]

65. Kong, Y.; Wang, J.; Kong, Z.; Song, F.; Liu, Z.; Wei, C. Small hydropower in China: The survey and sustainable future. Renew. Sustain. Energy Rev. 2015, 48, 425-433. [CrossRef]

66. Electricity Generation from Renewable Energy Sources in Poland-The Presidents of the Energy Regulatory Office Report in 2019 (In Polish: Wytwarzanie energii elektrycznej w Polsce w małych instalacjach OZE—Raport Prezesa URE za 2019 rok). Available online: https:/ /bip.ure.gov.pl/bip/o-urzedzie/zadania-prezesa-ure/raport-oze-art-17-ustaw/3556,Raport-zbiorczeinformacje-dotyczace-wytwarzania-energii-elektrycznej-z-odnawial.html (accessed on 10 July 2020).

67. Restor Hydro. Available online: http:/ / trmew.pl/index.php?id=151 (accessed on 10 April 2021).

68. Instytut Energetyki Odnawialnej. 2021. Available online: https://ieo.pl/en/pv-report (accessed on 15 April 2021).

69. Bochenek, B.; Jurasz, J.; Jaczewski, A.; Stachura, G.; Sekuła, P.; Strzyżewski, T.; Wdowikowski, M.; Figurski, M. Day-Ahead Wind Power Forecasting in Poland Based on Numerical Weather Prediction. Energies 2021, 14, 2164. [CrossRef] 
70. Kubiak-Wójcicka, K.; Bąk, B. Monitoring of meteorological and hydrological droughts in the Vistula basin (Poland). Environ. Monit. Assess. 2018, 190, 691. [CrossRef]

71. Solarczyk, A. The exhaustion of water resources in the Kuyavian-Pomeranian Voivodship in drought conditions in 2015. Res. Rural Dev. 2019, 1, 118-125. [CrossRef]

72. Jamorska, I.; Kubiak-Wójcicka, K.; Krawiec, A. Dynamics of the status of groundwater in the Polish Lowland: The River Gwda catchment example. Geologos 2019, 25, 193-204. [CrossRef]

73. Kubiak-Wójcicka, K.; Lewandowska, I. Changes in the surface area of lakes in the Gwda River basin. Limnolog. Rev. 2014, 3, 121-129.

74. Kubiak-Wójcicka, K.; Zeleňáková, M.; Purcz, P.; Simonová, D. The use of a Standardized Runoff Indicator for hydrological characterization of selected rivers of Poland and Slovakia. Middle Pomeranian Sci. Soc. Environ. Protect. 2019, 21, 167-183.

75. Kubiak-Wójcicka, K. Zmienność przepływów i zasobów wodnych Gwdy, In: Odpływ rzeczny i jego regionalne uwarunkowania. Ser. Studia Pr. Geogr. Geol. 2010, 12, 99-107. [CrossRef]

76. Kubiak-Wójcicka, K.; Kornaś, M. Impact of Hydrotechnical Structures on Hydrological Regime of the Gwda and Drawa Rivers. Quaest. Geogr. 2015, 34, 99-110. [CrossRef]

77. Tomaszewski, E.; Kubiak-Wójcicka, K. Low-Flows in Polish Rivers. In Management in Water Resources in Poland; Zeleňáková, M., Kubiak-Wójcicka, K., Negm, A.M., Eds.; Springer International Publishing: Cham, Switzerland, 2021; pp. $205-228$.

78. Runge, J. Metody Badań w Geografii Społeczno-Ekonomicznej-Elementy Metodologii, Wybrane Narzędzia Badawcze, 2nd ed.; Wydawnictwo Uniwersytetu Ślaskiego: Katowice, Poland, 2007.

79. Steller, J. Hydropower and its development. Acta Energetica 2013, 3, 7-20. [CrossRef]

80. Tomczyk, P.; Wiatkowski, M. Challenges in the Development of Hydropower in Selected European Countries. Water 2020, 12, 3542. [CrossRef]

81. Grill, G.; Lehner, B.; Lumsdon, A.E.; Macdonald, G.K.; Zarfl, C.; Liermann, C.R. An index-based framework for assessing patterns and trends in river fragmentation and flow regulation by global dams at multiple scales. Environ. Res. Lett. 2015, 10. [CrossRef]

82. Huđek, H.; Žganec, K.; Pusch, M.T. A review of hydropower dams in Southeast Europe-Distribution, trends and availability of monitoring data using the example of a multinational Danube catchment subarea. Renew. Sustain. Energy Rev. 2020, 117, 109434. [CrossRef]

83. Tzoraki, O. Operating Small Hydropower Plants in Greece under Intermittent Flow Uncertainty: The Case of Tsiknias River (Lesvos). Challenges 2020, 11, 17. [CrossRef] 